\title{
A Survey of Synthetic Routes and Antitumor Activities for Benzo[g]quinoxaline-5,10-diones
}

\author{
Alain G. Giuglio-Tonolo *, Christophe Curti, Thierry Terme and Patrice Vanelle * \\ Equipe Pharmaco-Chimie Radicalaire, Faculté de Pharmacie, Institut de Chimie Radicalaire, \\ Aix Marseille Université, CNRS, UMR 7273, 27 Boulevard Jean Moulin, CEDEX 05, 13385 Marseille, France; \\ christophe.curti@univ-amu.fr (C.C.); thierry.terme@univ-amu.fr (T.T.) \\ * Correspondence: gamal.giuglio-tonolo@univ-amu.fr (A.G.G.-T.); patrice.vanelle@univ-amu.fr (P.V.); \\ Tel.: +33-(0)4-9183-5580 (P.V.); Fax: +33-(0)4-9179-4677 (P.V.)
}

Received: 29 October 2020; Accepted: 9 December 2020; Published: 14 December 2020

\begin{abstract}
Anthracycline antibiotics play an important role in cancer chemotherapy. The need to improve their therapeutic index has stimulated an ongoing search for anthracycline analogs with enhanced properties. This review aims to summarize the common synthetic approaches to benzo[g]quinoxaline-5,10-diones and their uses in heterocyclic chemistry. Because of the valuable biological activities of the 1,4-diazaanthraquinone compounds, a summary of the most promising heterocyclic quinones is provided together with their antitumor properties.
\end{abstract}

Keywords: benzo[g]quinoxaline-5,10-dione; 1,4-diazaanthraquinone; anthracene-9,10-dione

\section{Introduction}

The substructure of 1,4-anthraquinones (anthracene-9,10-diones) is an important class of bioactive non-heterocyclic quinonoid compounds (Figure 1). They include natural anthracyclines such as Daunomycin, mainly active against acute lymphoblastic leukemia and acute myeloid leukemia, and Doxorubicin approved for the treatment of a wide variety of liquid and solid tumors [1]. The reference synthetic 1,4-anthraquinone is Mitoxantrone, with anticancer applications but also active on multiple sclerosis through its immunosuppressant properties [2]. Both drugs have adverse side effects typical of non-selective cytotoxic drugs, with inhibitor effects on rapidly dividing tissues (hair, bone marrow and mucous membranes). Moreover, 1,4-anthraquinones produce a dose-limiting specific toxicity to the heart. This has led to the development of many analogs with reduced toxicity and improved spectrum of activity [3]. Recently pixantrone, an aza-anthracenedione, was developed to reduce cardiotoxicity typically associated with anthracyclines but without compromising antineoplastic efficacy [4].

Numerous quinones are known for their anticancer activities, such as the alkylating agent Mitomycine C [5], or Streptonigrin obtained from Streptomyces flocculus, whose application is limited by its toxicity [6].

1,4-Diazaanthraquiones exhibit promising in vitro and in vivo activity against a wide spectrum of tumor cell lines [7-9]. They have been reported interesting antibiotic properties against a wide range of fungal and bacterial pathogens [5]. This review includes synthetic methodologies for the preparation of linear benzo[g]quinoxaline-5,10-diones derivatives and their structural analogs, as reported in the literature. Different strategies were found to give access to this class of compound, including:

- Condensations of 2,3-diamino-1,4-naphthoquinone with 1,2-dicarbonyl derivatives.

- Cycloaddition via generated in situ $N$-substituted-quinolinedione intermediates.

- Diels-Alder cyclocondensation reactions. 
The second part of the review summarizes the common biological activities of benzo[g]quinoxaline5,10-diones, with particular emphasis on their antitumor activity.<smiles>O=C1c2c(O)ccc(O)c2C(=O)c2c(NCCNCCO)ccc(NCCNCCO)c21</smiles>

Mitoxantrone<smiles>NCCNc1ccc(NCN)c2c1C(=O)c1cnccc1C2=O</smiles>

Pixantrone<smiles>CC1=C(N)C(=O)C2=C(C1=O)N1CC3NC1C23COC(N)=O</smiles>

Mitomycin C

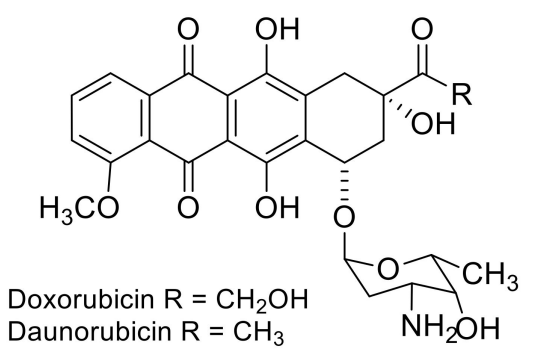<smiles>COC1=C(N)C(=O)c2nc(-c3nc(C(=O)O)c(C)c(-c4ccc(OC)c(OC)c4O)c3N)ccc2C1=O</smiles>

Figure 1. Structure of biologically active quinonoid compounds.

\section{Discussion}

\subsection{Synthesis of Benzo[g]quinoxaline-5,10-diones and Their Uses in Heterocyclic Chemistry}

\subsubsection{Synthesis from 2,3-Dichloro-1,4-naphthoquinone}

Many series of substituted benzo[g]quinoxaline-5,10-diones at the C-2 and C-3 positions were reported. These methods involved several steps. The 2,3-dichloro-1,4-naphthoquinone 1 is the most used substrate for the preparation of 1,4-naphthoquinone heteroannulated to a quinoxaline (also named benzo[ $g$ ]quinoxaline-5,10-diones) ring by multistep reactions synthesis (Scheme 1 ). The 2,3-dichloro-1,4-naphthoquinone 1 was used to obtain 2,3-diamino-1,4-naphthoquinone 2 (Scheme 2). This latter was condensed with a range of $\alpha$-dicarbonyl compounds.

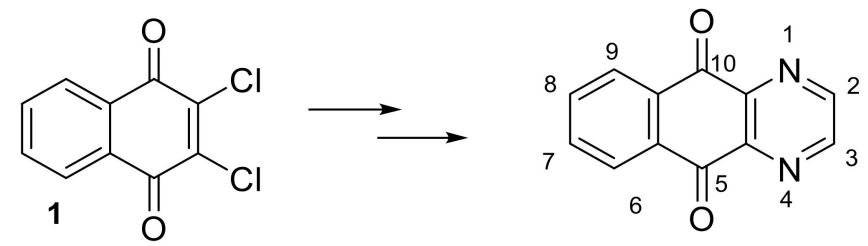

Scheme 1. Different multisteps synthesis to produce benzo[g]quinoxaline-5,10-dione derivatives from 2,3-dichloro-1,4-naphthoquinone $\mathbf{1 .}$

Reaction of 2,3-dichloro-1,4-naphthoquinone 1 with 2 equiv. of sodium azide produced a good yield of the diazido derivative, which was reduced with $\mathrm{Na}_{2} \mathrm{~S}_{2} \mathrm{O}_{4}$ to give 2,3-diamino-1,4-naphtho-quinone 2 (method a-Scheme 2) [10-14].

As an alternative, a Gabriel reaction can also be used. Phthalimide potassium with alkyl halides allows the synthesis of primary amines. After alkylation, the product was cleaved by reaction with hydrazine (method $\mathbf{b}-$ Scheme 2). In this case, the reaction of compound 1 with 2 equiv. of phthalimide potassium afforded diphthalimido naphthoquinone, which was allowed to react with hydrazine hydrate to give compound 2 also named 2,2-diamino[1,4]-naphtoquinone (Scheme 2) [15,16]. 
<smiles>O=C1C(Cl)=C(Cl)C(=O)c2ccccc21</smiles>

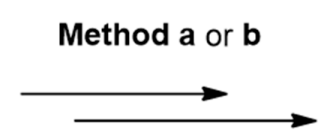

i. ii. iii. iv.<smiles>NC1=C(N)C(=O)c2ccccc2C1=O</smiles>

Method c \v. vi.<smiles>CC(=O)NC1=C(Cl)C(=O)c2ccccc2C1=O</smiles><smiles>CC(=O)NC1=C(N)C(=O)c2ccccc2C1=O</smiles><smiles>NC1=C(N)C(=O)c2ccccc2C1=O</smiles>

Method a. i) $\mathrm{NaN}_{3} 76 \%$. ii) $\mathrm{Na}_{2} \mathrm{~S}_{2} \mathrm{O}_{4} 70 \%$.

Method b. iii) Potassium phthalimide, $\mathrm{CH}_{3} \mathrm{CN}$ reflux, $90 \%$. iv) $\mathrm{N}_{2} \mathrm{H}_{4} \cdot \mathrm{H}_{2} \mathrm{O}, \mathrm{H}_{2} \mathrm{O}, 60{ }^{\circ} \mathrm{C}, 12 \mathrm{~h}$, $94 \%$.

Method c. v) $\mathrm{NH}_{3}$ gas / EtOH, $74 \%$. vi) $\mathrm{CH}_{3} \mathrm{COCl}, 81 \%$. vii). $\mathrm{NH}_{3}$ gas / 1,4-dioxane, $73 \%$. viii) $\mathrm{HCl}$ gas / $\mathrm{MeOH}, 77 \%$.

Scheme 2. Different synthesis ways to produce 2,3-diamino-1,4-naphthoquinone 2 or its hydrochloride form 5 .

Díaz et al. [17] synthesized compounds 3 as shown in Scheme 2 (method c) by melting $\mathbf{1}$ in ethanolic ammonia solution followed by acetylation. The acetylated compound 3 was suspended in an ammonia solution to obtain product 4. Hydrochloric acid gas was then added in methanol to derivative 4 (Scheme 2).

Most of the examples herein involve cyclization reactions of 2,3-diaminonaphthoquinones 2 with symmetrical $\alpha$-dicarbonyl compounds affording 2,3-disubstituted benzoquinoxaline- 5,10-diones as shown in Schemes 3 and 4 [18-24]. For example, compound 2 was allowed to react with bis(triisopropylsilyl)dialkynyl-1,2-dione in acetic acid to afford the corresponding compound 6a [20]. It was reported that refluxing compound 2 with 1,2-di(1H-pyrrol-2-yl)ethane-1,2-dione in glacial acetic acid gave 2,3-di(1H-pyrrol-2-yl)benzo[g]quinoxaline-5,10-dione $\mathbf{6 b}$ as illustrated in Scheme 3 [21].

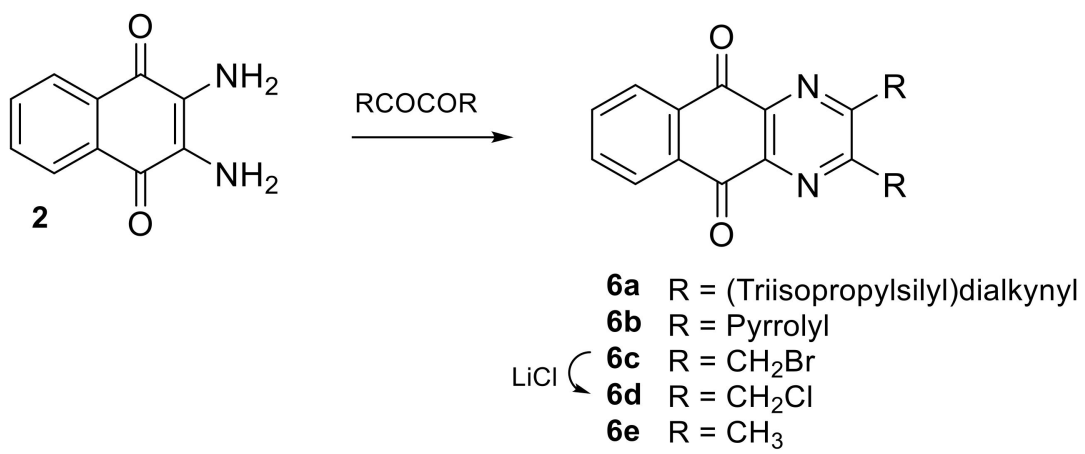

Scheme 3. 2,3-diamino-1,4-naphthoquinone 2 condensed with a range of symmetric $\alpha$-dicarbonyl compounds. 
<smiles>[R]OC(C)=O</smiles>

Scheme 4. 2,3-diamino-1,4-naphthoquinone 2 condensed with a range of non-symmetric $\alpha$-dicarbonyl compounds.

Condensation of compound 2 with 1,4-dibromobutane-2,3-dione led to 2,3-bis(bromomethyl)benzo[ $g]$ quinoxaline-5,10-dione 6c [18,22], which can be converted to its corresponding bis(chloromethyl) derivative by classical chlorination using lithium chloride [22]. Numerous reactions were also performed with unsymmetrical $\alpha$-dicarbonyl compounds (Scheme 4, Table 1).

Table 1. Synthetic 2,3-disubstituted benzoquinoxaline-5,10-diones.

\begin{tabular}{|c|c|c|c|}
\hline $\mathbf{N}^{\circ}$ & $\mathbf{R}_{1}$ & $\mathbf{R}_{2}$ & Ref. \\
\hline $6 a$ & (Triisopropylsilyl)dialkynyl & (Triisopropylsilyl)dialkynyl & [20] \\
\hline $6 b$ & Pyrrolyl & Pyrrolyl & [21] \\
\hline $6 c$ & $\mathrm{CH}_{2} \mathrm{Br}$ & $\mathrm{CH}_{2} \mathrm{Br}$ & {$[18,22]$} \\
\hline $6 \mathrm{~d}$ & $\mathrm{CH}_{2} \mathrm{Cl}$ & $\mathrm{CH}_{2} \mathrm{Cl}$ & [22] \\
\hline $6 e$ & $\mathrm{CH}_{3}$ & $\mathrm{CH}_{3}$ & {$[24]$} \\
\hline $6 f$ & Indolyl & Indolyl & [19] \\
\hline $6 f$ & 5-Bromo- $1 H$-indolyl & 5-Bromo- $1 H$-indolyl & [19] \\
\hline $6 h$ & Phenyl & Phenyl & [24] \\
\hline $6 i$ & Styryl & Styryl & [24] \\
\hline $6 j$ & $\mathrm{CH}_{3}$ & Phenyl & [24] \\
\hline $6 \mathrm{k}$ & $\mathrm{CH}_{3}$ & $\mathrm{H}$ & [24] \\
\hline 61 & $4-\mathrm{CF}_{3} \mathrm{C}_{6} \mathrm{H}_{4}$ & $\mathrm{CF}_{3}$ & [23] \\
\hline $6 \mathrm{~m}$ & $\mathrm{CH}_{3}$ & $3,5-\mathrm{diClC}_{6} \mathrm{H}_{4}$ & [23] \\
\hline $6 n$ & $\mathrm{CH}_{2} \mathrm{Cl}$ & $\mathrm{CH}_{2} \mathrm{CH}\left(\mathrm{CH}_{3}\right)_{2}$ & [23] \\
\hline 60 & $4-\mathrm{CH}_{3} \mathrm{C}_{6} \mathrm{H}_{4}$ & $4-\mathrm{FC}_{6} \mathrm{H}_{4}$ & [23] \\
\hline $6 p$ & $4-\mathrm{ClC}_{6} \mathrm{H}_{4}$ & $\mathrm{C}_{6} \mathrm{H}_{5}$ & [23] \\
\hline $6 q$ & $4-\mathrm{CH}_{3} \mathrm{C}_{6} \mathrm{H}_{4}$ & $4-\mathrm{ClC}_{6} \mathrm{H}_{4}$ & [23] \\
\hline
\end{tabular}

A non-exhaustive list of the substituents used in some of the most recent studies is presented in Table 1.

Reaction of 2 with oxalyl chloride afforded 7, which directly reacted with thionyl chloride to give the corresponding dichloride, followed by a Gabriel reaction to obtain the corresponding diamino-compound $\mathbf{8}$. Derivative $\mathbf{8}$ was then directly reacted with thionyl chloride or selenium oxychloride, to yield compound $\mathbf{9 a}$ and $\mathbf{9 b}$, respectively (Scheme 5) [25].

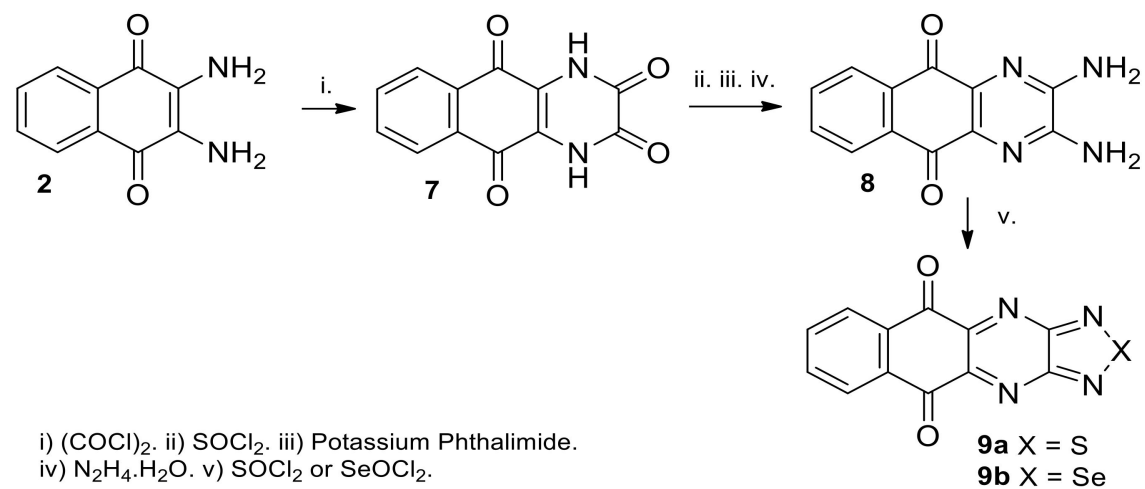

Scheme 5. Synthesis of benzo[g]quinoxaline-5,10-dione fused heterocyclic ring derivatives $\mathbf{9 a}$ and $\mathbf{9 b}$. 
Other polycyclic benzoquinoxalinediones were prepared from 2,3-diamino-1,4-naphthoquinone 2 by reaction with naphthalene-1,2-dione in $10 \%$ acetic acid and gave dibenzo $[a, i]$ phenazine- 8,13 -dione 10 [26]. A similar reaction of 2 with phenanthrene-9,10-dione and 1,10-phenanthroline-5,6-dione produced tribenzo[ $[a, c, i]$ phenazine-10,15-dione [16] 11a and benzo[i]dipyrido[3,2- $a: 2^{\prime}, 3^{\prime}-c$ phenazine10,15-dione [26-28] 11b, respectively (Scheme 6).

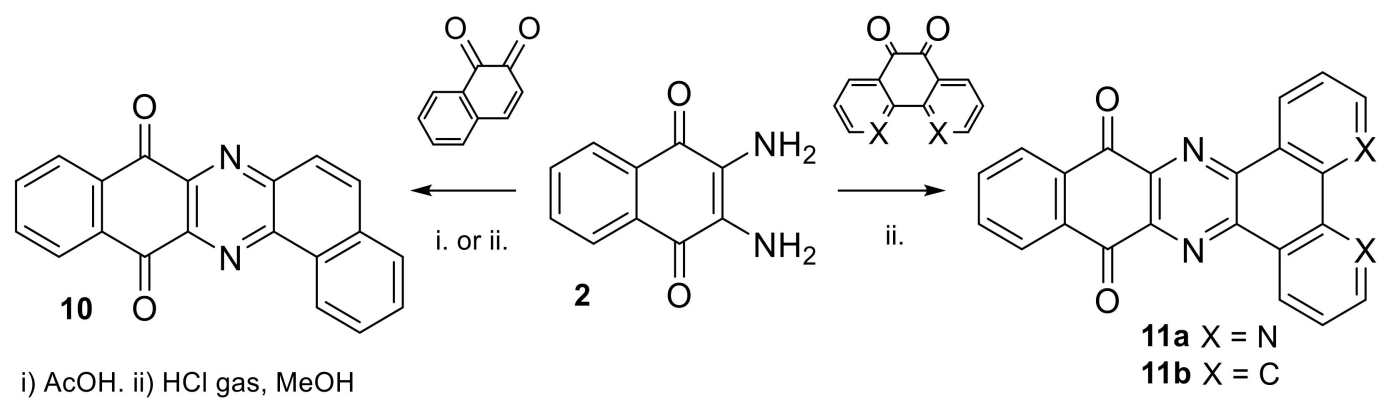

Scheme 6. Synthesis of polycyclic benzo[g]quinoxaline-5,10-diones $\mathbf{1 0}$ and $\mathbf{1 1 .}$

However, compound like $\mathbf{1 5 b}$ (Scheme 7) could not be obtained by the reaction of the title compound 2 with the $o$-phenylene diamine. Another synthetic strategy to obtain diazaanthraquinones is the following. In a first step, the intermediate 2-aminoquinones are usually synthesized via a Michael-type reaction of amines with 1,4-naphthoquinone [29] itself or with 2,3-dichloro-1,4-naphthoquionone [30,31]. In a second synthesis step the $N$-arylaminoquinolinedione derivatives obtained are subjected to $\mathrm{NaN}_{3} /$ moist DMF. Nakazumi et al. [32] obtained 7,10-dihydroxybenzo[b]phenazine-6,11-dione $(\mathrm{X}=\mathrm{OH}$ and $\mathrm{R}=\mathrm{H}) \mathbf{1 5 b}$ and 2-anilino-3-amino-5,8-dihydroxy-1,4-naphtoquinone $\mathbf{1 6 b}$ by reacting 2-anilino-5,8-dihydroxy- 1,4-naphtoquinone $13 \mathrm{~b}$ with sodium azide, in $29 \%$ and $42 \%$ yield respectively (Scheme 7). The reaction of 2-benzylamino-3-chloro-1,4-naphthoquinone 13a $(X=H, R=H)$ [33] with sodium azide was also used to obtain benzo[ $b]$ phenazine-6,11-dione 15a and 16a as secondary products.<smiles>[X]c1ccc([X])c2c1C(=O)C(Cl)=C(Cl)C2=O</smiles><smiles>[R]c1cccc(N)c1</smiles>

i. or ii.

$1 \mathrm{X}=\mathrm{H}$

$12 \mathrm{X}=\mathrm{OH}$<smiles>[R]c1ccc2nc3c(nc2c1)C(=O)c1c([X])ccc([X])c1C3=O</smiles>

a $X=H, R=H$

b $\mathrm{X}=\mathrm{OH}, \mathrm{R}=\mathrm{H}$

c $X=\mathrm{H}, \mathrm{R}=2-\mathrm{CH}_{3}$

d X $=\mathrm{H}, \mathrm{R}=3-\mathrm{CH}_{3}$

e $\mathrm{X}=\mathrm{H}, \mathrm{R}=\mathrm{O}\left(\mathrm{CH}_{2}\right)_{5} \mathrm{CH}_{3}$<smiles>[R]c1cccc(NC2=C(N)C(=O)c3c([X])ccc([X])c3C2=O)c1</smiles>

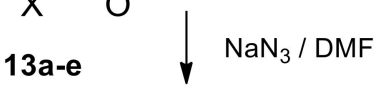

i) Aryl amines, EtOH reflux. with $\mathrm{R}=\mathrm{H}, 4-\mathrm{Cl}, 2-\mathrm{CH}_{3}, 3-\mathrm{CH}_{3}, 2,5-\mathrm{diOCH}$, 3,5-diOCH $\mathrm{CH}_{3}$, 2,4-diOCH 3 and $4-\mathrm{O}\left(\mathrm{CH}_{2}\right)_{5} \mathrm{CH}_{3}$. ii) Aryl amines, $\mathrm{CeCl}_{3}$ with $\mathrm{R}=\mathrm{H}, 2-\mathrm{OCH}_{3}, 4-\mathrm{OCH}_{3}, 4-\mathrm{OCH}_{2} \mathrm{CH}_{3}, 4-\mathrm{F}, 3,4-\mathrm{diF}$.

Scheme 7. Synthetic strategy to obtain diazaanthraquinones. 
Kurban et al. [34] synthesized (2-chloro-3-tolylamino)naphthalene-1,4-dione ( $\mathrm{X}=\mathrm{H}, \mathrm{R}=2$ - or 3- $\left.\mathrm{CH}_{3}\right)$ from 2,3-dichloro-1,4-naphthoquinone 1, which when reacted with sodium azide $\left(\mathrm{NaN}_{3}\right)$ in moist DMF, afforded 1- or 2-methylbenzo[b]phenazine-6,11-dione 15c or $\mathbf{1 5 d}$ as the only isolated products (Scheme 7).

Most of the derivatives $\mathbf{1 3}$ can also be obtained through a nucleophilic substitution by reacting a substituted aniline with 2,3-dichloronaphthoquinone using $\mathrm{CeCl}_{3}$ as catalyst. Addition of this latter induces the formation of a complex between the carbonyl function and $\mathrm{Ce}^{3+}$. Thus, selective nucleophilic substitution takes place [35], with a chlorine atom replaced by a substituted aniline (68-90\% yields with $\mathrm{R}=\mathrm{H}$; 4-OMe; 4-OEt; 2-F; 4-F; 3,4-diF; 2-OMe).

This approach is an easy way to synthesize tetracyclic linear diazaanthraquinone. The scope is limited by the variety of substituents when $N$-aryl is synthesized. Substituted anilines with electron-donating groups are quite reactive and afford high yields of the corresponding anilinoquinones. However, using either method with anilines substituted with electron-withdrawing groups gives quite low yields. As a consequence, these methods may not be used for the preparation of nitro substituted-2-(4-arylamino)-1,4-naphthoquinones. However, they can be obtained by an alternative two-step synthesis was developed. In the first step, 2-anilino-3-chloro-1,4-naphthoquinones were prepared by the classical Michael type addition-elimination reaction $[33,36]$. The phenyl group was then nitrated via direct electrophilic aromatic substitution in the second step.

The nucleophilic displacement reaction of compounds $\mathbf{1 7 a - j}$ or 2 -chloro-3-(R-anilino)-1,4naphthoquinones with sodium azide led to a vinylazide intermediates 18a-j [35] (Scheme 8). Under heating, only few of these intermediates underwent thermal decomposition via intramolecular oxidative ring closure and yielded 6,11-dihydropyrido[2,3-b]phenazine-6,11-diones 19b-d (Scheme 8).<smiles>[R2]c1ccc(NC2=C(Cl)C(=O)c3ccccc3C2=O)c([R17])c1NC1=C(N)C(=O)c2cc(C(C)(C)C)ccc2C1=O</smiles>

$$
\begin{array}{ll}
\mathrm{R}_{1}=\mathrm{H}, \mathrm{R}_{2}=\mathrm{H} & \mathbf{a} \\
\mathrm{R}_{1}=\mathrm{OCH}_{3}, \mathrm{R}_{2}=\mathrm{H} & \mathbf{b} \\
\mathrm{R}_{1}=\mathrm{H}, \mathrm{R}_{2}=\mathrm{OCH}_{3} & \mathbf{c} \\
\mathrm{R}_{1}=\mathrm{OCH}_{2} \mathrm{CH}_{3}, \mathrm{R}_{2}=\mathrm{H} & \mathbf{d} \\
\mathrm{R}_{1}=\mathrm{F}, \mathrm{R}_{2}=\mathrm{H} & \mathbf{e} \\
\mathrm{R}_{1}=\mathrm{Cl}, \mathrm{R}_{2}=\mathrm{H} & \mathbf{f} \\
\mathrm{R}_{1}=\mathrm{NO}_{2}, \mathrm{R}_{2}=\mathrm{H} & \mathbf{g} \\
\mathrm{R}_{1}=\mathrm{CO}_{2} \mathrm{Et}, \mathrm{R}_{2}=\mathrm{H} & \mathbf{h} \\
\mathrm{R}_{1}=\mathrm{NO}_{2}, \mathrm{R}_{2}=\mathrm{H} & \mathbf{I}
\end{array}
$$

Scheme 8. Synthesis of 6,11-dihydropyrido[2,3-b]phenazine-6,11-diones 19 by nucleophilic displacement reaction of or 2-chloro-3-( $R$-anilino)-1,4-naphthoquinones 17.

Azides reduction (Staudinger reaction) is often limited by the formation of a secondary product (2-aryl- or 2-alkyl-amino-3-azido-1,4-naphthoquinone) from such reactions. Ring closure is promoted by azidonaphthoquinones bearing electron-rich substituents ( $\mathrm{R}=\mathrm{OMe}, \mathrm{OEt}, \mathrm{OBut})$. The formation of arylaminonaphthoquinone derivatives is promoted by electron-withdrawing substituents. Based on Wasserman's observations [37] regarding the mechanism of arylnitrene cyclisation could be explained in terms of singlet and/or triplet nitrene chemistry [35].

Azidonaphthoquinones having an electron-withdrawing substituent favor the generation of an open-shell nitrene with a strong biradical character, which undergoes hydrogen abstraction to give $N$-aminonaphthoquinone (Scheme 9). In contrast, azidonaphthoquinones having a strong electron-donor like O-R favor the generation of a highly reactive singlet nitrene which undergoes insertion to give a tetracyclic compound (Scheme 10). 
<smiles>[NH2+]C1=C(NC2C=CC(=[N+]([O-])[O-])C=C2)C(=O)c2ccccc2C1=O</smiles>

Scheme 9. Proposed mechanism for the synthesis of $\mathrm{N}$-aminonaphthoquinones from azidonaphthoquinones bearing electron-withdrawing substituent.<smiles>[R]Oc1ccc(N=c2c(=Nc3cc(N=C4C(=O)c5ccccc5C(O)=C4N)ccc3O[R])c(=O)c3ccccc3c2=O)cc1</smiles>

Scheme 10. Proposed ring closure reaction mechanism for the synthesis of diazaanthraquinones. from azidonaphthoquinones bearing electron-rich substituents.

When tricyclic dichloroquinone 20 reacts with arylamines, the intermediate mononitrogenated was obatained, from which further reaction with sodium azide afforded the expected linear pentacyclic naphtophenazinediones 21-23 in moderate to low yields (Scheme 11) with retaining the $p$-quinone system [38].

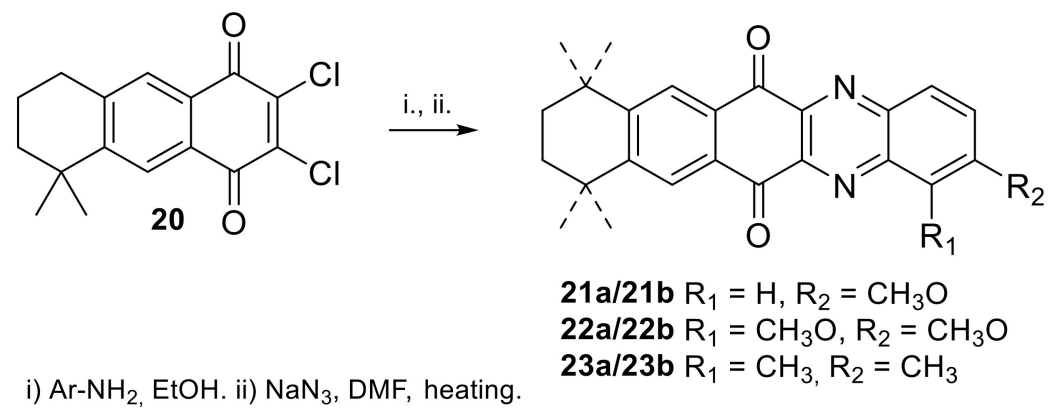

Scheme 11. Synthesis of pentacyclic naphtophenazinediones 21-23 from tricyclic dichloroquinone 20.

When the crude diazido compound, obtained from 6-nitro or 5-nitro-2,3-dichloro-1,4naphthoquinones $24 \mathrm{a}$ and $\mathbf{2 4 b}$ was subjected to reduction with sodium dithionite followed by air oxidation, the triamino-1,4-naphthoquinone 25a was obtained in 72\% yield [32]. Compound 25a was then condensed to glyoxal and yielded amino substituted benzo[g]quinoxaline-5,10-dione $26 \mathbf{a}(92 \%)$ as shown in Scheme 12 [39]. 


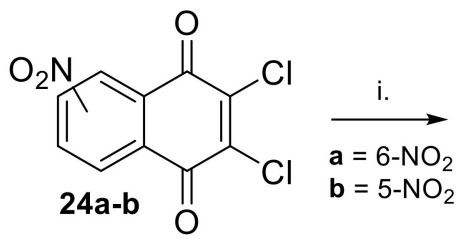<smiles>NC1=C(N)C(=O)c2ccccc2C1=O</smiles><smiles>CC(C)(C)COC(=O)c1ccccc1N</smiles>

i) $\mathrm{NaN}_{3} / \mathrm{Na}_{2} \mathrm{~S}_{2} \mathrm{O}_{4}$. ii) glyoxal

Scheme 12. Synthesis of amino substituted benzo[g]quinoxaline-5,10-diones 26 from nitro-2,3dichloro-1,4-naphthoquinones 24 .

The preparation of disubstituted derivatives of benzo[b]phenazine-6,11-quinones was reported [32]. Reduction of $\mathbf{1 5 b}$ with sodium dithionite gave an intermediate compound which was reacted without purification with aqueous ammonia, methylamine or aniline to give, after subsequent oxidation, 7-10-diamino derivatives 27 (Scheme 13).<smiles>O=C1c2nc3ccccc3nc2C(=O)c2c(O)ccc(O)c21</smiles><smiles>Nc1ccccc1</smiles>

i) $\mathrm{RNH}_{2} / \mathrm{Na}_{2} \mathrm{~S}_{2} \mathrm{O}_{4}$. ii) air oxydation<smiles>[R]Nc1ccc(N[R])c2c1C(=O)c1nc3ccccc3nc1C2=O</smiles>

$\mathrm{R}=\mathrm{H}, \mathrm{CH}_{3}$, Phenyl

Scheme 13. Synthesis of disubstituted benzo[b]phenazine-6,11-quinones 27.

Interestingly, 2-arylamino-1,4-naphthoquinones $28 \mathbf{a}-\mathbf{d}$ treated with nitrosylsulfuric acid in acetic acid are converted to benzo[b]phenazine-6,11-dione oxides $29 a-d$. Usually the 2-arylamino3-chloro-1,4-naphthoquinones in reaction with $\mathrm{HNO}_{3} / \mathrm{H}_{2} \mathrm{SO}_{4}$ are nitrated on the arylamino group [36]. Thus, the reaction of aminoquinones 28a-d with nitrosylsulfuric acid takes another pathway than that described in the literature. Compounds $\mathbf{2 9 a} \mathbf{a} \mathbf{d}$ are obtained from aminoquinones $\mathbf{2 8} \mathbf{a}-\mathbf{d}$ in high yields and can be further modified. For example, phenazine $\mathrm{N}$-oxide 29a was reduced with hydrazine to benzo[b]phenazine-6,11dione 30a in 89\% yield (Scheme 14) [40].

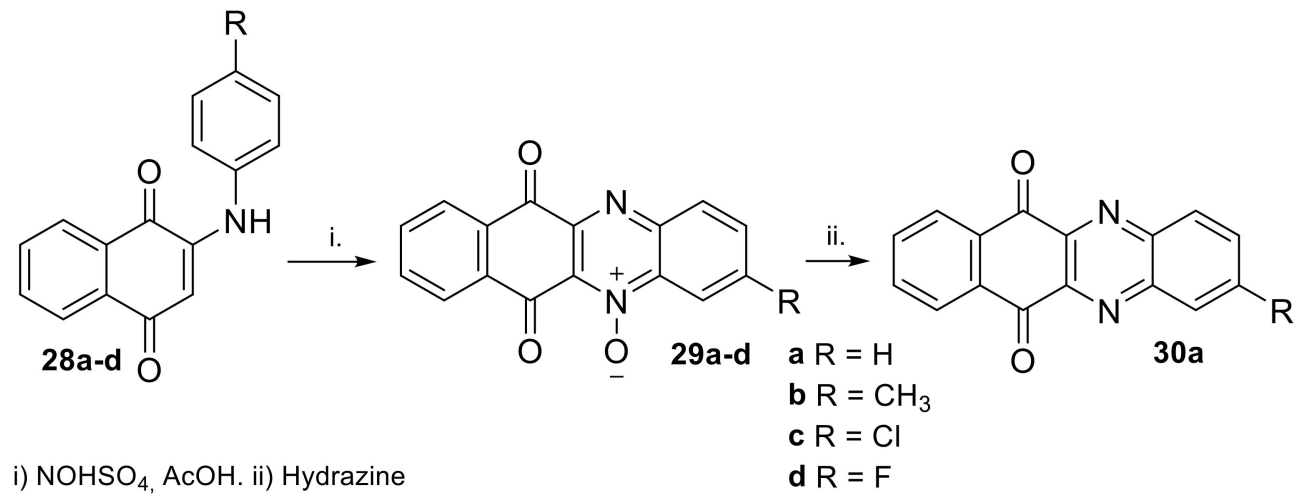

Scheme 14. Synthesis of benzo[g]quinoxaline-5,10-diones 30a from 2-arylamino-1,4-naphthoquinones 28.

It has been suggested, that the cyclization of 2-nitrosodiarylamines to the corresponding phenazine $\mathrm{N}$-oxides [41] takes place upon treatment with nitrous acid. A mechanism involving radical cations is postulated for such cyclizations (Scheme 15), even though these fail to be detected. Notably, compounds $\mathbf{2 8}$ treated with nitrosylsulfuric acid in concentrated sulfuric acid failed to convert to products 29 even after prolonged stirring. 
<smiles>[R]c1ccc(N=C2C(=O)c3ccccc3C(=O)C2N=C2C=C([N+](C)(C)C)C(=O)c3ccccc3C2=O)cc1</smiles>

Scheme 15. Proposed mechanism for the formation of phenazine N-oxide 29.

\subsubsection{Synthesis from 5,8 -quinoxalinedione}

The synthetic routes towards the construction of the benzo[g]quinoxaline-5,10-diones core from 5,8-quinoxalinedione were also studied [42,43].

4-Aminophenol $\mathbf{3 1}$ can be used as starting material. The diacetylation of $\mathbf{3 1}$ with acetic anhydride and triethylamine was achieved in $87 \%$ yield and was followed by nitration with fuming nitric acid to give mononitro compound 32 in $87 \%$ yield. The selective deacetylation of $\mathbf{3 2}$ was obtained using methanolic potassium carbonate at $0{ }^{\circ} \mathrm{C}(91 \%)$. Careful temperature control below $5{ }^{\circ} \mathrm{C}$ for nitration of 33 with $61 \%$ nitric acid gave single isomer 2,3-dinitro-compound 34 in 79\% yield. Compound 34 was then hydrogenated in the presence of Raney Ni catalyst to afford 2,3-diamino-4-acetaminophenol, which was not isolated and reacted with glyoxal to form compound 35 in $79 \%$ yield. Compound 35 was readily converted to 36 with refluxing $2 \mathrm{~N}$ sulfuric acid. Unisolated intermediate 36 reacted with sodium chlorate in hydrochloric acid solution at $0{ }^{\circ} \mathrm{C}$ to form 6,7-dichloro-5,8-quinoxalinedione 37 in $63 \%$ overall yield in eight steps, easily substituted with nucleophiles (Scheme 16). It is interesting to note that the title compound 37 was previously prepared in 3\% yield in six steps [43].

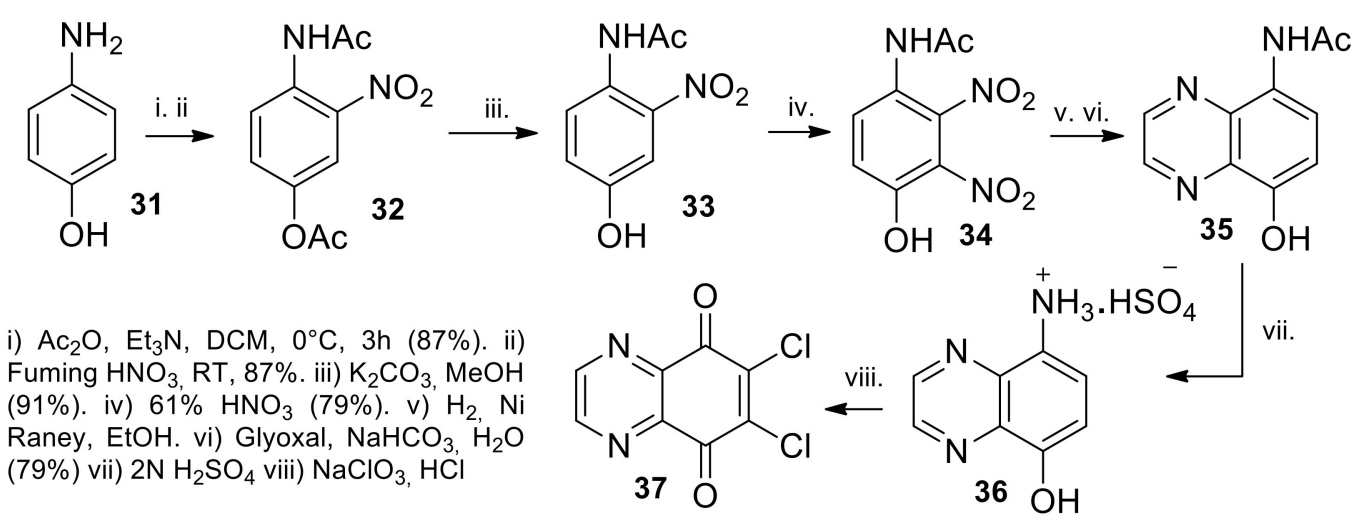

Scheme 16. Synthesis of 6,7-dichloro-5,8-quinoxalinedione 37.

Reaction of diaminoquinoxalinedione 38 with glyoxal in water [39] gave 5,10-pyrazino[2,3-g] quinoxalinedione 39a. 2,3-Dialkyl-5,10-pyrazino[2,3-g]quinoxalinediones $39 \mathbf{b}-\mathbf{d}$ [44] were obtained by 
reacting diaminoquinoxalinedione with 1,2-diketones in 50\% aqueous acetic acid. 2,3-Diphenyl5,10-pyrazino[2,3-g]quinoxalinedione 39e was obtained from the reaction of 6,7-diamino-5,8quinoxalinedione 38 with benzil in ethanol using catalytic concentrated sulfuric acid (Scheme 17).

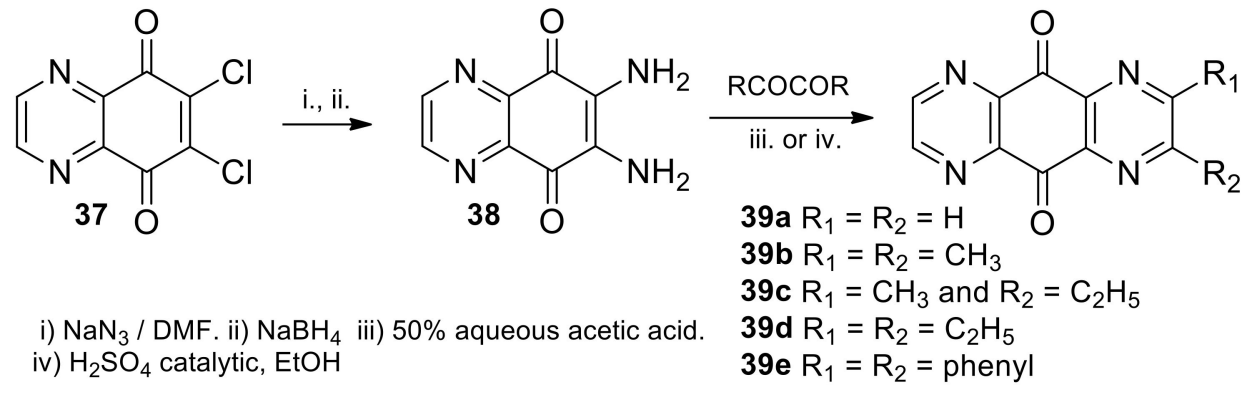

Scheme 17. Synthesis of 5,10-pyrazino[2,3-g]quinoxalinediones 39 from 6,7-dichloro-5,8-quinoxalinedione 37.

When a mixture of 6-bromo-7-methoxy-5,8-quinoxalinedione 40 and 1,1-diarylethylene derivatives was irradiated by $\mathrm{Hg}$ lamp at $300 \mathrm{~W}$ in presence of pyridine, naphtho[1,2-g]quinoxaline-7,12-dione derivatives 41 were isolated. Evidence was obtained that the photoreaction involved a photoinduced electron-transfer process (Scheme 18) [45].<smiles>COC1=C(Br)C(=O)c2nccnc2C1=O</smiles><smiles>[R]Oc1ccccc1C(=C)c1cccc(Br)c1</smiles><smiles>[R]c1cccc2c3c(cc([121I])c12)C(=O)c1nccnc1C3=O</smiles>

Scheme 18. Synthesis of naphtho[1,2-g]quinoxaline-7,12-diones 41.

The effect of electron-withdrawing and electron-donating groups on the reaction of 6,7-dichloro5,8-quinoxalinedione 37 with dinucleophilic reagents was examined (Scheme 19). The reaction of 37 with 4-methoxy-1,2-phenylenediamine gave condensation compound corresponding to angulated annelated product 42. The reaction with 4-nitro-1,2-phenylenediamine, because of the weak basicity of the amine, was not able to produce the condensation compound by ring closure; only $\mathbf{4 3}$ was isolated [46]. With aminopyridine, pyrido[1,2-a]imidazo[4,5-g]quinoxaline-6,11-dione 44 was obtained. Reaction mechanism can be either nucleophilic substitution or nucleophilic addition (Scheme 19) [46].

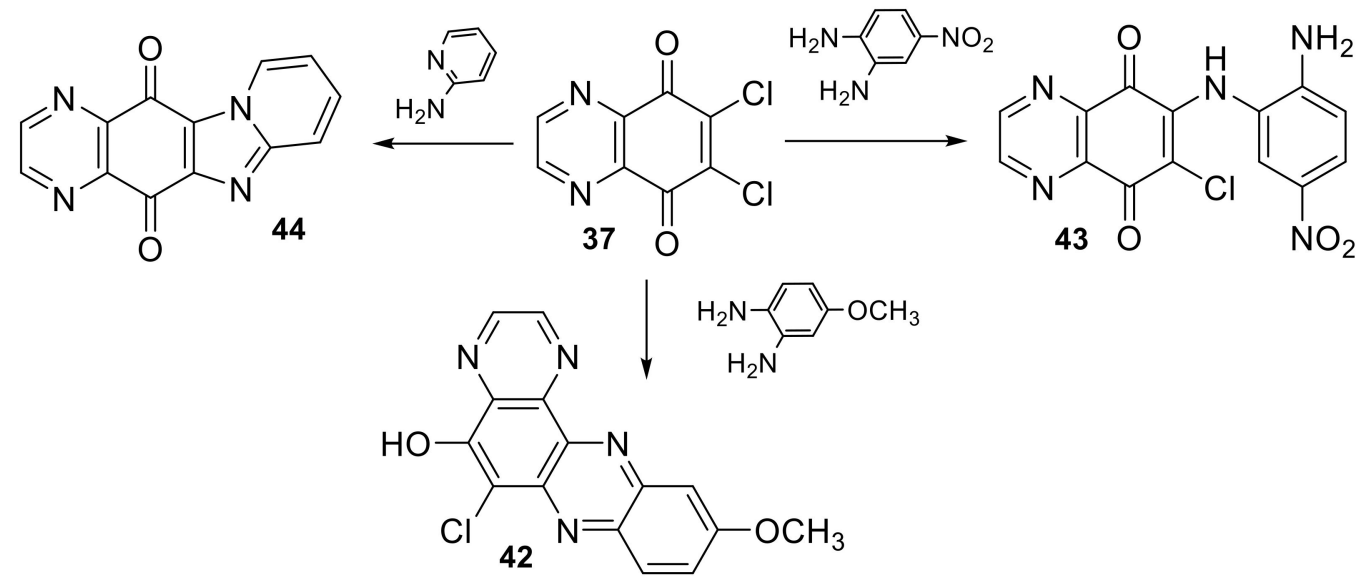

Scheme 19. Reactions of 6, 7-dichloro-5, 8-quinoxalinedione 37 with aromatic dinucleophiles. 


\subsubsection{Miscellaneous Reactions}

The synthesis of 6,9-bis-[(aminoalkyl)amino]- substituted benzo[g]quinoxalines was described [47-51]. They were prepared by displacements $\left(S_{N} A r\right)$ of the fluorides from 6,9-difluoro- substituted benzo[g]quinoxaline. The diacid was converted into the anhydride by refluxing in acetic anhydride or by treatment with DCC in THF. Friedel-Crafts acylation of 1,4-difluorobenzene with the anhydride in the presence of aluminium chloride led to keto acid 46. Cyclodehydratation of 46 to 47 was obtained with fuming sulfuric acid at $140{ }^{\circ} \mathrm{C}$. Addition of $N, N$-dimethylethylenediamine to a pyridine solution of 47 yielded 48a. Fluoride displacements proceeded quite slowly and the mixture was stirred for several days to complete the bis-substitution. Shortening the reaction time would the mono-substituted analog to be isolated. $\mathbf{4 8 b}$ and its mono-substituted analog were prepared by treatment of $N$-(tert-butoxycarbonyl)ethylenediamine in DMSO (Scheme 20).

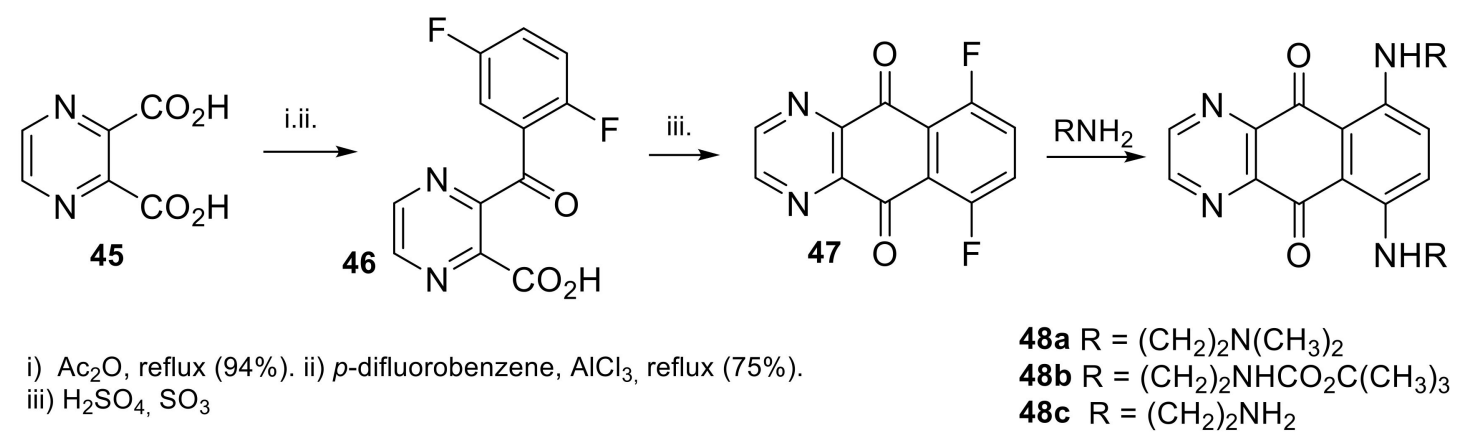

Scheme 20. Synthesis of disubstituted benzo[g]quinoxaline-5,10-diones 48 from pyrazine-2,3dicarboxylic acid 45 .

The above synthetic pathway had the disadvantage to synthesize benzo[g]quinoxalinediones in which both distal side arms were the same. Krapcho et al. [48] accomplished subsequently the synthesis of regioisomeric dihalo-substituted heterocyclic quinone named 6-chloro-9- fluorobenzo[ $g$ ]quinoxaline 56. This molecule 56 can be used as starting material for the synthesis of dialkylamino-substituted heterocyclic quinones by fluoride and chloride on the C-6 and C-8 positions. The fluoride will undergo an $S_{N} A r$ displacement at room temperature at a rate considerably more rapid than the chloride, on being treated with amine nucleophiles. The mono-chlorosubstituted compound being treated at a higher temperature with a different amine derivative (or any other nucleophilic species) will lead to the desired compounds. The synthesis of compound 56 is detailed on Scheme 21.

3-Aminopyrazine-2-carboxylic acid 49 was converted into 3-hydroxypyrazine-2-carboxylic acid 50 by diazotation and by heating the resulting diazonium salt in water. The corresponding acid was then converted into pyrazine ester $\mathbf{5 1}$ using dry hydrogen chloride in methanol. Chloroester $\mathbf{5 2}$ obtained by treatment with phosphorus oxychloride treated with the organozinc reagent derived from 53 in the presence of dichlorobis(triphenylphosphine)palladium and afforded 54. This latter was hydrolyzed and led to the desired 6-chloro-9-fluorobenzo[g]quinoxaline 56. This synthetic regioselective pathway avoids the Hayashi-type rearrangements [52] encountered during cyclizations of this family of keto acids (Scheme 21). A non-exhaustive list of diazabioisosteres of mitoxantrone 57 a-1 already synthesized is summarized in Table 2. 
<smiles>Nc1nccnc1C(=O)O</smiles><smiles>C1CCCCC1</smiles><smiles>O=C(O)c1nccnc1O</smiles><smiles>c1ccc(C2CC2)cc1</smiles>

50<smiles>Fc1ccc(Cl)c(CBr)c1</smiles>

53<smiles>O=C1c2nccnc2C(=O)c2c(Cl)ccc(F)c21</smiles><smiles>C#CC</smiles><smiles></smiles><smiles>CC#CCCCC</smiles>

52<smiles>Cc1cc(F)c(C[18O])c(Cl)c1</smiles><smiles>CC(C)(C)C(=O)O</smiles><smiles>CC(=O)c1nccnc1Cc1cc(Cl)ccc1F</smiles>

i) $\mathrm{NaNO}_{2}, \mathrm{HCl}$ and heating in $\mathrm{H}_{2} \mathrm{O}$. ii) $\mathrm{HCl}, \mathrm{MeOH}$. iii) $\mathrm{POCl}_{3}$. iv) $\mathrm{Zn}, \mathrm{THF}$ and $\mathrm{NiCl}_{2}\left[\mathrm{P}\left(\mathrm{C}_{6} \mathrm{H}_{5}\right)_{3}\right]_{2}$ v) $\mathrm{NaOH}, \mathrm{MeOH}$. vi) $\mathrm{H}_{2} \mathrm{SO}_{4}, \mathrm{SO}_{3}$.

Scheme 21. Synthesis of 6-chloro-9-fluorobenzo[ $g$ ]quinoxaline 56 from 3-aminopyrazine-2-carboxylic acid 49.

Table 2. Synthetic diazabioisosteres of Mitoxantrone.

\begin{tabular}{|c|c|c|c|c|}
\hline $\mathbf{N}^{\circ}$ & $\mathbf{R}$ & $\mathbf{R}_{1}$ & $\mathbf{R}_{2}$ & Ref. \\
\hline $57 a$ & $\mathrm{Me}$ & $\mathrm{H}$ & $\mathrm{OMe}$ & [49] \\
\hline $57 \mathrm{~b}$ & $\mathrm{Me}$ & $\mathrm{NHCO}_{2} \mathrm{Et}$ & $\mathrm{NHCO}_{2} \mathrm{Et}$ & [49] \\
\hline $57 \mathrm{c}$ & $\mathrm{Me}$ & $\mathrm{NH}_{2}$ & $\mathrm{NH}_{2}$ & [49] \\
\hline $57 \mathrm{~d}$ & $\mathrm{H}$ & $\mathrm{OCH}_{3}$ & $\mathrm{H}$ & [50] \\
\hline $57 \mathrm{e}$ & $\mathrm{H}$ & $\mathrm{NH}_{2}$ & $\mathrm{H}$ & {$[49,51]$} \\
\hline $57 f$ & $\mathrm{H}$ & $\mathrm{F}^{2}$ & $\mathrm{NH}\left(\mathrm{CH}_{2}\right)_{2} \mathrm{~N}(\mathrm{Me})_{2}$ & [47] \\
\hline $57 \mathrm{~g}$ & $\mathrm{H}$ & $\mathrm{F}$ & $\mathrm{NH}\left(\mathrm{CH}_{2}\right)_{2} \mathrm{NHCO}_{2} \mathrm{C}(\mathrm{Me})_{3}$ & [47] \\
\hline $57 \mathrm{~h}$ & $\mathrm{H}$ & $\mathrm{OH}$ & $\mathrm{OH}$ & [50] \\
\hline $48 a$ & $\mathrm{H}$ & $\mathrm{NH}\left(\mathrm{CH}_{2}\right)_{2} \mathrm{~N}(\mathrm{Me})_{2}$ & $\mathrm{NH}\left(\mathrm{CH}_{2}\right)_{2} \mathrm{~N}(\mathrm{Me})_{2}$ & [47] \\
\hline $48 b$ & $\mathrm{H}$ & $\mathrm{NH}\left(\mathrm{CH}_{2}\right)_{2} \mathrm{NHCO}_{2} \mathrm{C}(\mathrm{Me})_{3}$ & $\mathrm{NH}\left(\mathrm{CH}_{2}\right)_{2} \mathrm{NHCO}_{2} \mathrm{C}(\mathrm{Me})_{3}$ & [47] \\
\hline $48 c$ & $\mathrm{H}$ & $\mathrm{NH}\left(\mathrm{CH}_{2}\right)_{2} \mathrm{NH}_{2}$ & $\mathrm{NH}\left(\mathrm{CH}_{2}\right)_{2} \mathrm{NH}_{2}$ & [47] \\
\hline $57 \mathrm{i}$ & $\mathrm{H}$ & $\mathrm{F}$ & $\mathrm{F}$ & [47] \\
\hline $57 \mathrm{j}$ & $\mathrm{H}$ & $\mathrm{F}$ & $\mathrm{Cl}$ & [48] \\
\hline $57 \mathrm{k}$ & $\mathrm{Me}$ & $\mathrm{H}$ & $\mathrm{OCH}_{3}$ & [49] \\
\hline 571 & $\mathrm{Me}$ & $\mathrm{H}$ & $\mathrm{OMe}$ & [49] \\
\hline
\end{tabular}

Aryl- or alkylbenzo[b]phenazines 58a-c, treated with a boiling solution of chromic acid/AcOH, resulted in the oxidation of benzophenazines to 2,3-aryl- or 2,3-alkyl-benzo[b]phenazine-6,11-diones 59a-c, respectively (Scheme 22) [33,53]. 


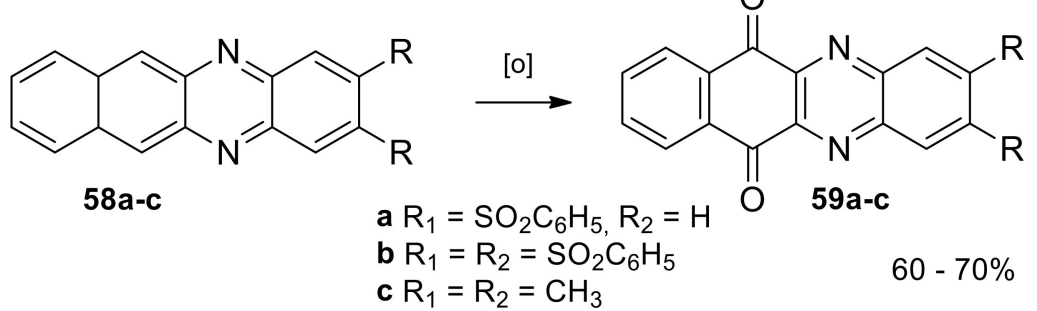

Scheme 22. Synthesis of 2,3-substituted-benzo[b]phenazine-6,11-diones 59.

2,3-Diaminonaphthalene was synthesized by successive chlorinations of 2,3-dihydroxynaphthalene 60 with $\mathrm{POCl}_{3}$ and amination using $\mathrm{NH}_{3} / \mathrm{NH}_{4} \mathrm{Cl}$. The quinoxaline ring system was synthesized by reaction of ortho-phenylenediamine with $\alpha, \beta$-dicarbonyl moieties. 2,3-Diphenylbenzo[g]quinoxaline $\mathbf{6 2}$ was obtained by oxidation of compound $\mathbf{6 1}$ with $\mathrm{CrO}_{3}$ in $\mathrm{AcOH}$ (Scheme 23) [54].
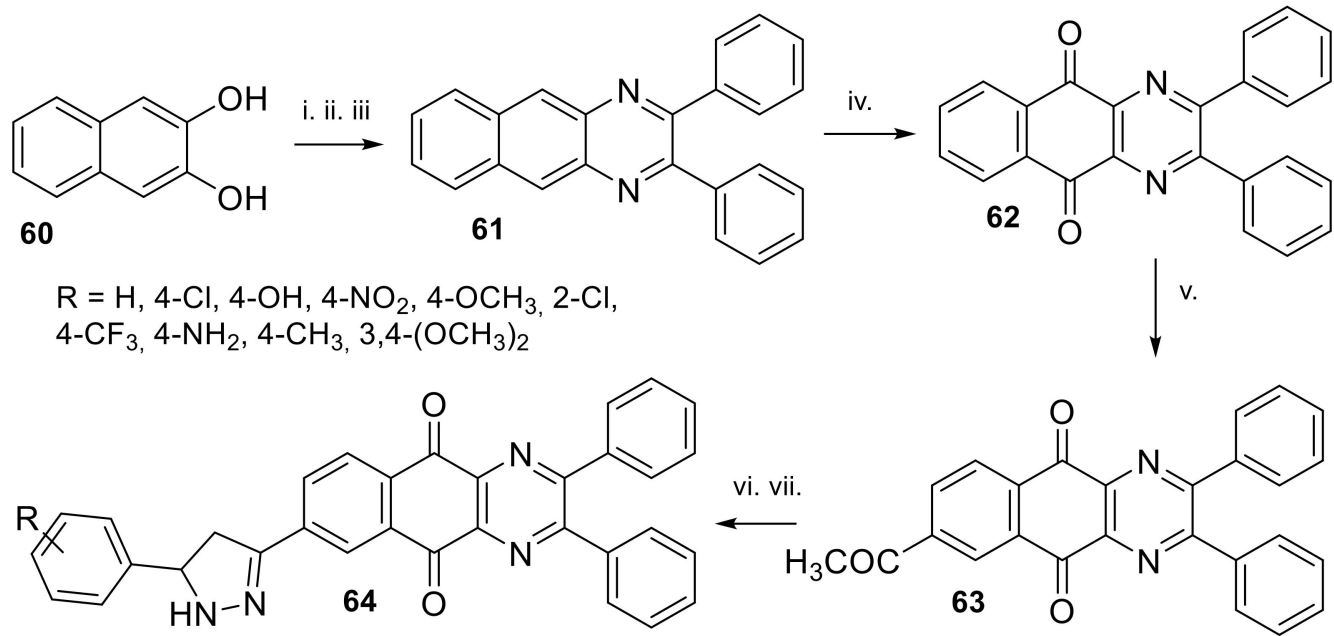

i) $\mathrm{POCl}_{3}$, reflux, 4h. ii) $\mathrm{NH}_{3}, \mathrm{NH}_{4} \mathrm{Cl}$, reflux at water bath, 6h. iii) Benzil, EtOH, 2h. iv) $\mathrm{CrO}_{3} / \mathrm{AcOH}$, reflux, 2h. v) $\mathrm{AlCl}_{3}, \mathrm{CCl}_{4}$, reflux, 6h. vi) $\mathrm{R}-\mathrm{C}_{6} \mathrm{H}_{4}-\mathrm{CHO}, \mathrm{KOH}, \mathrm{MeOH}, 0-5^{\circ} \mathrm{C}$. vii) $\mathrm{NH}_{2}-\mathrm{NH}_{2}, \mathrm{H}_{2} \mathrm{O}, \mathrm{EtOH}$, reflux.

Scheme 23. Synthesis of 7-substituted-2,3-diphenylbenzo[g]quinoxaline-5,10-dione 64 from 2,3-dihydroxynaphthalene 60.

Microwave-assisted synthesis of fused pyrazolo[3,4-b]pyrazines 66 obtained by the reaction of orthoaminonitrosopyrazoles 65 and cyclic $\alpha$-diketones was described (Scheme 24) [55]. Microwave irradiation is known to simplify and improve classic organic reactions, because it often leads to higher yields, cleaner and shorter reactions with precise control of its parameters [55].

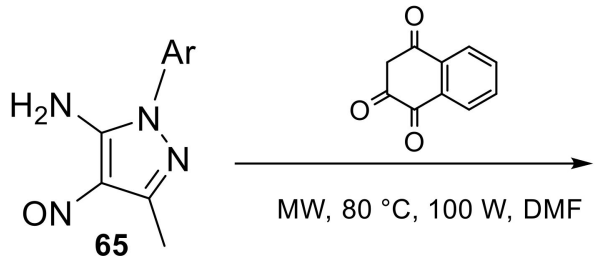

$\mathrm{Ar}=\mathrm{C}_{6} \mathrm{H}_{5}, 4-\mathrm{ClC}_{6} \mathrm{H}_{4}, 4-\mathrm{BrC}_{6} \mathrm{H}_{4}, 4-\mathrm{CNC}_{6} \mathrm{H}_{4}$<smiles>Cc1nn([Al])c2nc3c(nc12)C(=O)c1ccccc1C3=O</smiles>

$45-63 \%$

Scheme 24. Synthesis of fused pyrazolo[3,4-b]pyrazines 66 under microwave radiation.

A proposed mechanism [55] for the cyclocondensation reaction is outlined in Scheme 25. The reaction starts with a nucleophilic addition of the activated methylene to the nitroso group 
of pyrazole 65 , forming imino intermediate 67 . This addition is favored by the higher nucleophilicity of the activated methylene of the amino group of the pyrazole. Subsequently, intermediate 67 cyclizes via the remaining $\mathrm{NH}_{2}$ group with the terminal side chain carbonyl group $(\mathrm{C}=\mathrm{O})$ to form final pyrazolopyrazine 66 after dehydration (Scheme 25).<smiles>Cc1nn([Al])c2c1C(=O)C(C)(C)C2=O</smiles>

Scheme 25. Synthesis of pyrazolopyrazine derivative 66 .

p-Dimethoxybenzene 69 can also be used as starting material. Nitration of 69 was performed in acetic acid with concentrated nitric acid followed by reduction with $\mathrm{H}_{2} / \mathrm{Pd} / \mathrm{C}$ in ethyl acetate gave a mixture of compounds 70a-b [56]. The regioisomers were separated in the next reaction step. Only compound 70a gave quinoxaline $\mathbf{7 1}$ during the reaction with 2,3-butanedione, which could then be separated easily from the byproduct $\mathbf{7 0 b}$. Compound $\mathbf{7 1}$ was then transferred into compound $\mathbf{7 2}$ by reaction with $\mathrm{AlCl}_{3}$. Condensation of 2,3-dimethyl-5,8-dihydroxyquinoxaline $\mathbf{7 2}$ and $o$-phthalaldehyde gave 2,3-dimethylnaphtho[2,3-g]quinoxaline-5,12-dione 73 in 70\% yield [57] as shown in Scheme 26.

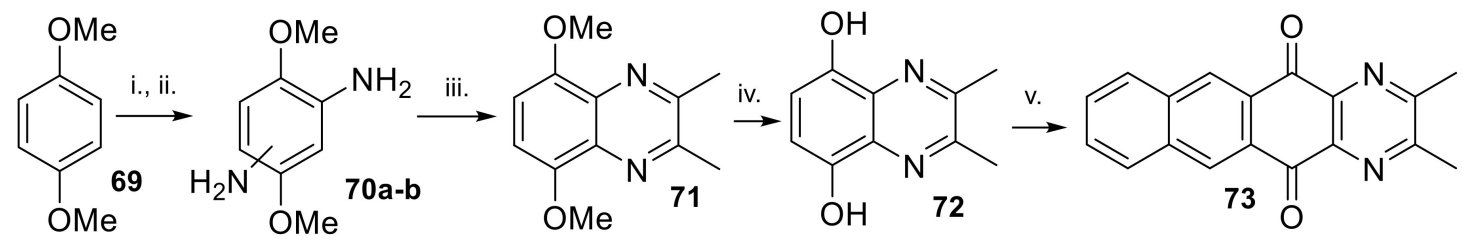

i) $\mathrm{HNO}_{3} / \mathrm{AcOH}(84 \%)$. ii) $\mathrm{H}_{2}, \mathrm{Pd} / \mathrm{C}$, EtOAc (79 \%). iii) 2,3-butanedione, $\mathrm{AcOH}(89 \%)$. iv) $\mathrm{AlCl}_{3}$, toluene $(73 \%)$. v) o-phthalaldehyde, $\mathrm{Na}_{2} \mathrm{CO}_{3}, \mathrm{CF}_{3} \mathrm{CO}_{2} \mathrm{H}(70 \%)$.

Scheme 26. Synthesis of 2,3-dimethylnaphtho[2,3-g]quinoxaline-5,12-dione 73 from $p$-dimethoxybenzene 69.

\subsubsection{Diels-Alder Reactions}

Diels-Alder reactions of quinones with a variety of polarized dienes are efficient methods to synthesize highly substituted diazaanthraquinones. Quinoxaline quinones can serve as useful dienophiles in [4+2]-cycloaddition reactions. They were obtained via a Hinsberg reaction from the condensation of $o$-diamine 75 with glyoxal [58] or 2,3-butanedione [58,59] followed by ceric ammonium nitrate (CAN) oxidation to afford $\mathbf{7 6} \mathbf{a}$ and $\mathbf{7 6 b}$ ( $68 \%$ and $85 \%$ overall yield, respectively) as shown in Scheme 27.

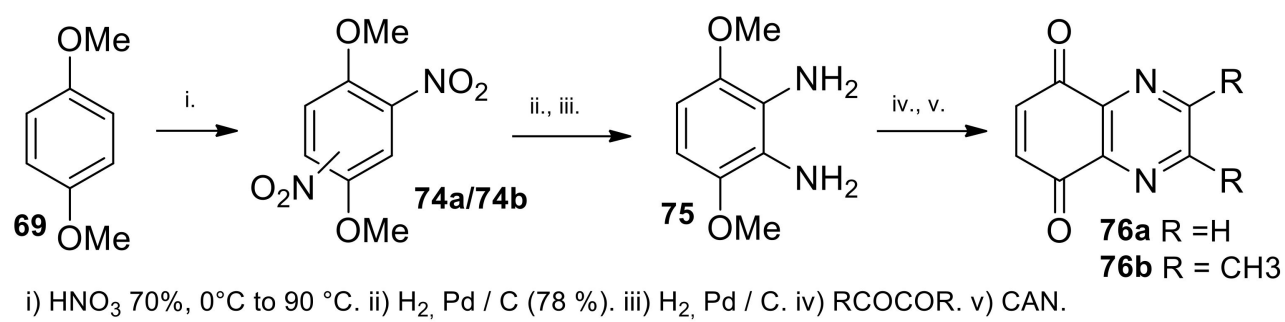

Scheme 27. Synthesis of quinoxaline-5,8-dione derivatives 76 from $p$-dimethoxybenzene 69.

The synthetic pathway starts with the nitration of 1,4-dimethoxybenzene 74 . The obtained mixture of dinitro compounds isomers can be reduced by different methods $[43,60]$ or separated 
before the reduction step [61,62]. With $\mathrm{NO}_{3} / \mathrm{O}_{3}$ in dichlomethane at $0{ }^{\circ} \mathrm{C}$ [61], a good yield $(81 \%)$ was obtained in the mixture of compounds 75a (1,4-dimethoxy-2,3-dinitrobenzene) and 75b (1,4-dimethoxy2,5-dinitrobenzene), with no selectivity (54/46 respectively). The $\mathrm{NO}_{2} / \mathrm{BF}_{3}$ in dimethoxyethane at $-50{ }^{\circ} \mathrm{C}$ [63] led to regioisomers $74 \mathrm{a} / 74 \mathrm{~b}$ in $76 \%$ yield with an excellent regioselectivity (100/0). A step-by-step reduction was found to be advantageous, allowing 0 -amino 75 to be easily isolated in good yield. Such a stepwise procedure avoids the separation of $\mathbf{7 5 a} \mathbf{a} \mathbf{7 5 b}$ or the corresponding diamines (Scheme 27) [60].

Preparation of quinoxaline-5,8-dione 76a is reported in the literature [64]. Benzo[ $g$ ]quinoxaline5,10-dione derivatives bearing 7-dialkylaminomethyl were synthesized based on the Diels-Alder reaction of quinoxaline-5,8-dione 76a with isoprene [65], as outlined in Scheme 28. Starting material 76a was treated with isoprene to give the cycloaddition adduct, which was directly aromatized by aerial oxidation in $5 \mathrm{~N}$ ethanolic $\mathrm{KOH}$ under reflux to give 7-methylbenzo[g]quinoxaline-5,10-dione 78. Intermediate $\mathbf{7 8}$ was then treated by $\mathbf{N}$-bromosuccinimide (NBS) and a catalytic amount of benzoylperoxide in anhydrous 1,2-dichloroethane under reflux for $48 \mathrm{~h}$ with irradiation by tungsten lamp to give bromomethyl product 79 in $30 \%$ yield (Scheme 28).<smiles>[R]Cc1ccc2c(c1)C(=O)c1nccnc1C2=O</smiles>

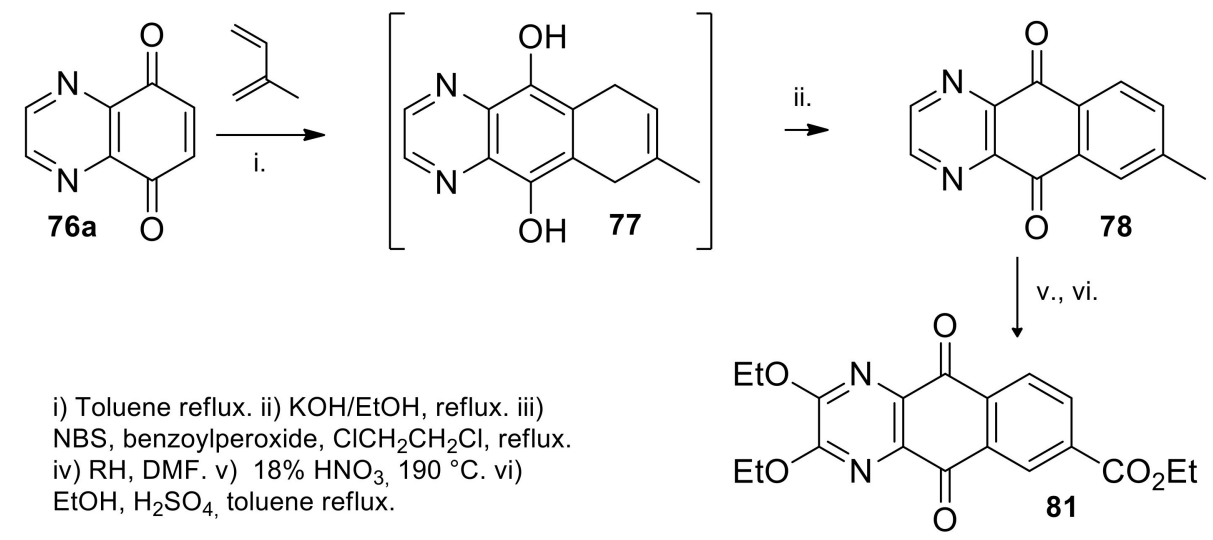

Scheme 28. Synthesis of 7-methylbenzo[ $g$ ] quinoxaline-5,10-dione $\mathbf{7 8}$ used as starting material for the preparation of 1,4-diazaanthracenes 80 and $\mathbf{8 1}$.

Starting material 76a was treated with 2,3-dimethylbutadiene to give the cycloaddition adduct, which was directly aromatized by aerial oxidation in ethanolic $\mathrm{KOH}$ under reflux to give 6,7-dimethylbenzo[g]quinoxaline-5,10-dione 82 [66,67]. The required intermediate 82 was treated with $N$-bromosuccinimide (NBS) and a catalytic amount of benzoylperoxide under irradiation to give the corresponding bisbromomethyl product in $42 \%$ yield. Target compounds 83 containing alkyl or cycloalkyl substituents were synthesized by direct substitution reaction of the bisbromomethyl compound with the corresponding alkylamine, and afforded alkyl- substituted triazacyclopenta[b]anthracene-5,10-dione derivatives in 30\% to $81 \%$ yield (Scheme 29 ). 


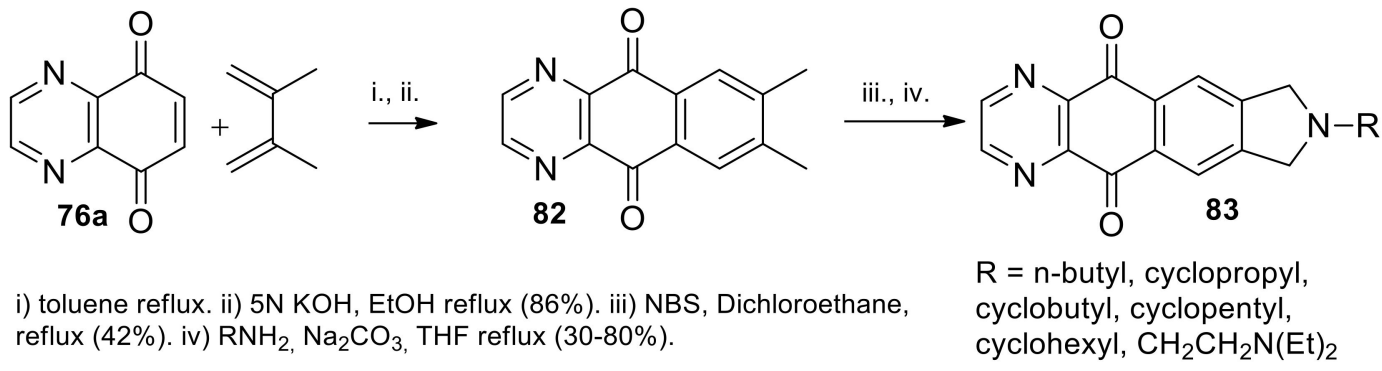

Scheme 29. Synthesis of alkyl-substituted triazacyclopenta[b]anthracene-5,10-diones 83 from quinoxaline-5,8-dione 76a.

Further reactions of compounds 82 with $18 \% \mathrm{HNO}_{3}$ in a Parr-type A-30397 titanium pressure reactor afforded the corresponding dicarboxylic acid 84. The crude product heated to reflux in $\mathrm{SOCl}_{2}$, and subsequent treatment of this crude with a number of alkyl- or arylamines, led to compounds $\mathbf{8 5 a - j}$ in $16 \%$ to $31 \%$ global yields (Scheme 30) [67].<smiles>Cc1cc2c(cc1C)C(=O)c1nccnc1C2=O</smiles>

$85 a \mathrm{R}=\operatorname{propyl}(56 \%)$ 85b R = phenyl $(30 \%)$

i) $18 \% \mathrm{HNO}_{3}, 190^{\circ} \mathrm{C}$. ii) $\mathrm{SOCl}_{2}$, reflux / $\mathrm{N}_{2}$. iii) $\mathrm{RNH}_{2}, \mathrm{Ac}_{2} \mathrm{O}, \mathrm{NaOAc}$. 85h R $=3-\mathrm{OMe}^{-} \mathrm{C}_{6} \mathrm{H}_{4}(33 \%)$

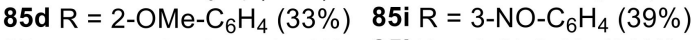

85e $\mathrm{R}=2-\mathrm{NO}_{2}-\mathrm{C}_{6} \mathrm{H}_{4}(30 \%) \quad 85 \mathrm{j} \mathrm{R}=4-\mathrm{Cl}-\mathrm{C}_{6} \mathrm{H}_{4}(36 \%)$

Scheme 30. Synthesis of $\mathrm{N}$-trisubstituted 2,3-diamino- $5 \mathrm{H}$-isoindolo[5,6- $\mathrm{g}]$ quinoxaline-5,7,9,11(8H)-tetraones 85 from 7,8-dimethylbenzo[g]quinoxaline-5,10-dione 82.

7,8-Dimethylbenzoquinoxalinediones are useful as starting materials for the synthesis of tricyclic quinones through the Diels-Alder reaction.

Cycloadditions with cyclic dienes are expected to occur with formation of a 1:1-cycloadduct, followed by tautomerization and ready oxidation. This yields a bridged ring system which can undergo thermal elimination of ethylene to afford diazaanthraquinone [51]. Cycloadditions of 1,3-cyclohexadiene with the other heterocyclic quinones also yielded initial 1:1-cycloadducts 86, which were isolated directly from the reaction mixture. Conversion into the oxidized quinone with silver oxide and thermal elimination of ethylene afforded diazaanthraquinones in high yields (Scheme 31).<smiles>CCOc1ccc([Se])cc1</smiles>

Scheme 31. Synthesis of 2,3,7,8-tetramethylbenzo[g]quinoxaline-5,10-dione $\mathbf{8 8}$ from 2,3-dimethylquinoxaline-5,8-dione $76 \mathbf{b}$.

2,3-Dimethylquinoxaline-5,8-dione $\mathbf{7 6 b}$ was reacted with silyloxyl dienes (Scheme 32) in refluxing benzene, giving trihydroxy compound 89 (90\%). Acetylation of trihydroxy compound 89 afforded the corresponding acetate which, after oxidation, was converted into quinone 91. As shown 
in Scheme 32, Danishefsky's diene (trans-1-methoxy-3-[(trimethylsilyl)oxy]-1,3-butadiene) easily underwent cycloaddition with the quinone $\mathbf{7 6 b}$ to directly afford oxidized cycloadduct 91 ( $71 \%)$.

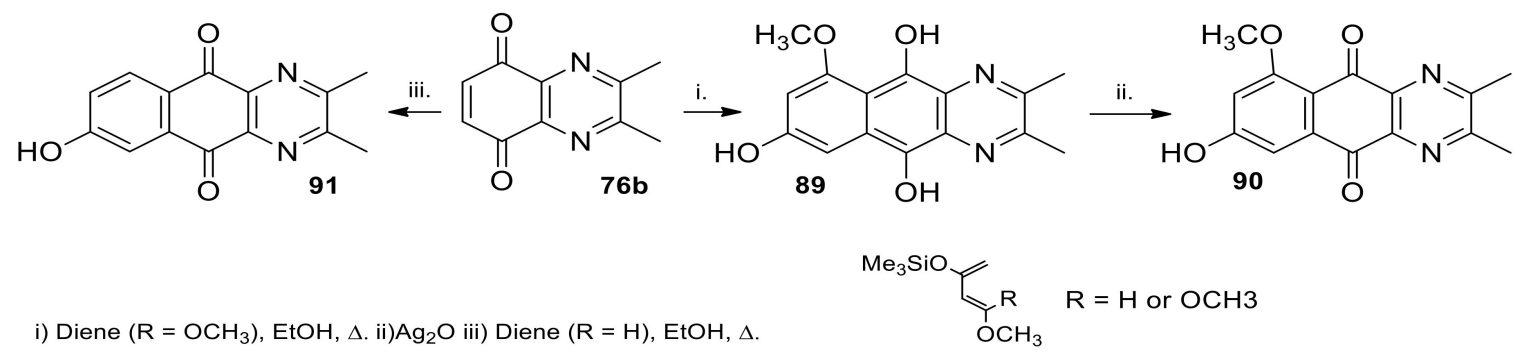

Scheme 32. Diels-Alder reactions between 2,3-dimethylquinoxaline-5,8-dione $\mathbf{7 6 b}$ and silyloxyl dienes.

The total synthesis of pyrazine analogs of 1,1-deoxydaunomycin was reported. Treatment of sodium salts generated from tetrahydrohomophthalic anhydride (Scheme 33) with derivative $\mathbf{7 6} \mathbf{b}$ gave cycloadducts 92 and 93, regioselectively [68]. These adducts were converted to pyrazine analogs of 1,1-deoxydaunomycin 94 and 95.

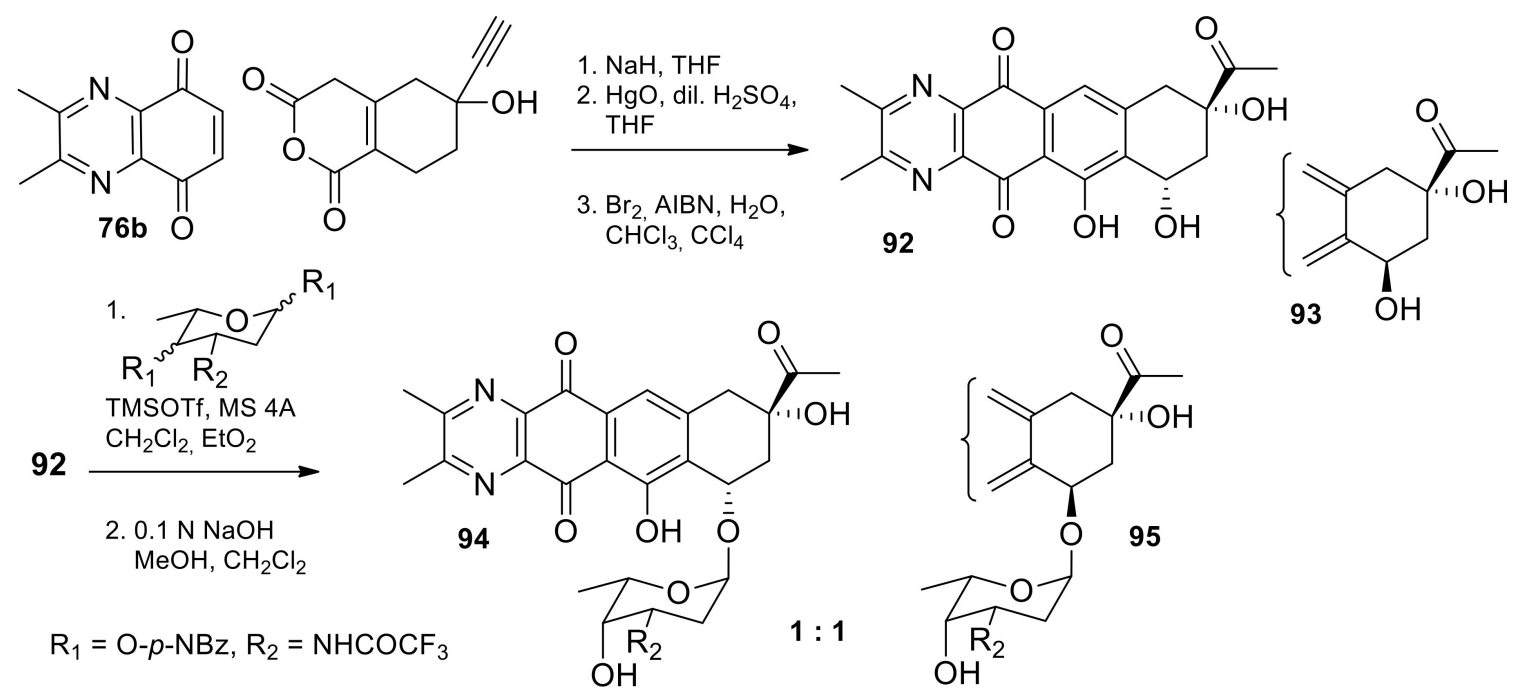

Scheme 33. Synthesis of pyrazine analogs of 1,1-deoxydaunomycin 94 and 95.

Treatment of the sodium salts cited above with mercury(II) oxide and diluted sulfuric acid, followed by bromination with bromine and AIBN, gave cis-diol 92 in 27\% yield. The respective configurations of $\mathbf{9 2}$ and $\mathbf{9 3}$ were determined from proton nuclear magnetic resonance (1H-NMR) spectral data [69]. Condensation of racemic 92 with tetrahydropyrane derivative followed by base hydrolysis gave $\alpha$-glycosides $\mathbf{9 4}$ and 95 as an inseparable 1:1 mixture of two diastereomers in $48 \%$ yield (Scheme 33).

A useful approach to the synthesis of anthracyclinone derivatives (Scheme 34) is the Diels-Alder using quinone 98 [70]. The latter was obtained ( $88 \%$ yield) by oxidation of 1,4-diol 97a with lead tetraacetate, or directly from 1,4-dimethoxy precursor $97 \mathrm{~b}$ [71] with silver oxide in nitric acid [72] ( $40 \%$ yields). Successful oxidation of 96 (via the di-O-acetate) to di- $\mathrm{N}$-oxide was reported [71]. 


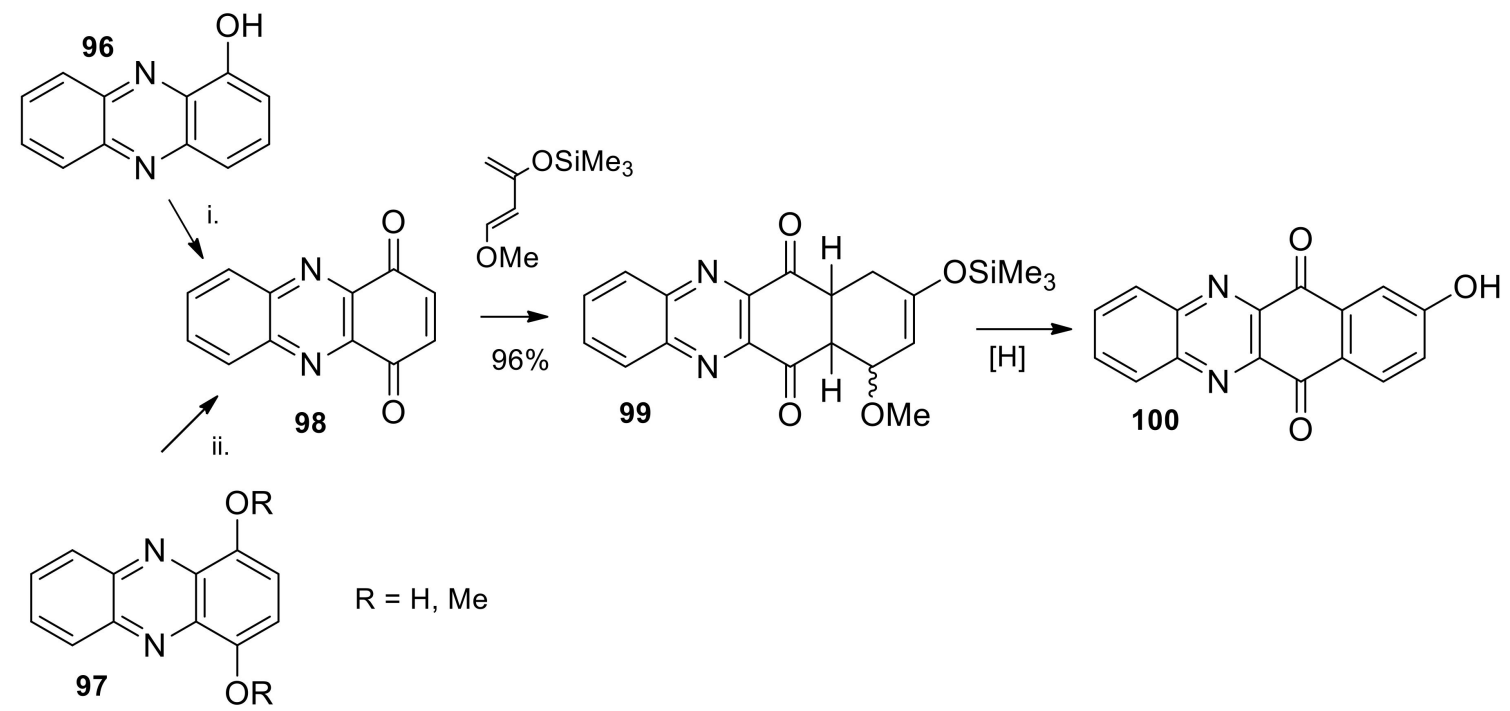

Scheme 34. Synthesis of 8-hydroxybenzo[b]phenazine-6,11-dione 100 by Diels-Alder using quinone 98.

Quinone 98, unoxidized at the nitrogen atom, proved to be a good dienophile with reactive 1-methoxy-3-(trimethylsilyloxy)-1,3-butadiene [73]. The reaction occurred at room temperature to give the normal adduct 99 in $96 \%$ yield. Adduct 99, prone to aromatization, gave elimination product 100 [70].

\subsection{Antitumor Activities}

Tricyclic diazaquinones exhibit strong anticancer activity [48]. One of the cytostatic action mechanisms of coplanar polycyclic compounds is their intercalation with human DNA. This caused enzymatic blockade and reading errors during the replication process [74]. Compounds having three to four coplanar rings, appear to give the optimal intercalation. More annelated heterocyclic quinones were reported to increase antitumor activity [75]. The electrochemical properties of quinone compounds are obviously very important for their bioreduction to semiquinone and/or hydroquinone. The replacement of two carbons at the phenyl ring of the 1,4-naphthoquinone core by two nitrogen atoms increased the oxidant nature of the molecules in accordance with both redox potential and substrate efficiencies [76].

2,3-Diethyl-5,10-pyrazino[2,3-g]quinoxalinedione 39d, prepared from 6,7-dichloroqui-noxaline5,8-dione 37 in 59\% overall yield in three steps [39] exhibited potent cytotoxic activity against human gastric adenocarcinoma cells ( $\mathrm{IC}_{50}=1.30$ and $7.61 \mu \mathrm{M}$, respectively). Both compounds bearing bulky side chains are supposed to interact with DNA and form a stable complex (Figure 2).<smiles>CCc1nc2c(nc1CC)C(=O)c1nccnc1C2=O</smiles>

Figure 2. Structure of 2,3-diethyl-5,10-pyrazino[2,3-g]quinoxalinedione 39d.

Many heterocyclic quinones act as topoisomerase inhibitors via DNA-intercalation. Topoisomerases are DNA-modifying enzymes essential to the control of DNA topology. They are involved in all cellular processes (replication, transcription, chromatin condensation and recombination) in which the topology of the DNA molecule must be changed without changing its chemical structure. Some pyridophenazinediones [77] showed potent activity against human stomach cancer cells (Figure 3). The possible mechanism of this action is suggested to be a DNA topo I and topo II inhibition. The best 
representatives are compounds $101\left(\mathrm{IC}_{50}=0.06 \mu \mathrm{M}\right.$ on SK-OV-3), prepared from 6,7-dichloroquinoline5,8-dione in $38 \%$ overall yield in two steps, and $102\left(\mathrm{IC}_{50}=0.06 \mu \mathrm{M}\right.$ on $\left.\mathrm{XF}-498\right)$, prepared from 6,7 -dichloroquinoline-5,8-dione in $23 \%$ overall yield in two steps.<smiles>[R]c1ccc2nc3c(nc2c1[R])C(=O)c1ncccc1C3=O</smiles>

$101 \mathrm{R}_{1}=\mathrm{OCH}_{2} \mathrm{CH}_{3}$ and $\mathrm{R}_{2}=\mathrm{H}$

$102 \mathrm{R}_{1}=\mathrm{R}_{2}=\mathrm{CH}_{3}$

Figure 3. Structure of pyridophenazinediones 101 and 102.

Giorgi-Renault prepared benzoquinoxalinediones and examined their antitumor activities [18]. 2,3-Bis(bromomethyl)-5,10-benzo[g]quinoxalinedione 6c, prepared from 2,2-diamino[1,4]-naphtoquinone $\mathbf{2}$ in 75\% yield in one step, exhibited cytotoxicity and was highly active, especially against sarcoma (Figure 4).<smiles>O=C1c2ccccc2C(=O)c2nc(CBr)c(CBr)nc21</smiles>

Figure 4. Structure of 2,3-bis(bromomethyl)benzo[g]quinoxaline-5,10-dione 6c.

The tumor suppressor p53 is a central mediator of apoptosis from chemically induced stress. Doxorubicin causes activation of p53 in both diploid and tetraploid cells due to a lack of polyploid cell line-specific selectivity. Recently, 2,3-diphenyl-1,4-diazaanthraquinone (DPBQ) 62 was proven to be a selective lead compound for the treatment of high-ploidy breast cancer, which activates p53 and triggers apoptosis of tumor cells (Figure 5) [78]. This latter compound appears to be limited to high-ploidy cell types with intact p53. It does not inhibit topoisomerase or bind DNA. Mechanistic analysis demonstrates that DPBQ 54, obtained from the National Cancer Institute (NCI) elicits a hypoxia gene signature and its effect is replicated, in part, by enhancing oxidative stress.<smiles>O=C1c2ccccc2C(=O)c2nc(-c3ccccc3)c(-c3ccccc3)nc21</smiles>

Figure 5. Structure of 2,3-diphenylbenzo[g]quinoxaline-1,5-dione 62.

A number of 6,7-modified 5,8-quinoxalinedione derivatives containing nitrogen, sulfur and oxygen exhibited cytotoxic effects on human lung, gastric and colon adenocarcinoma cells when compared with cis-platin and adriamycin, commonly used anticancer drugs [79].

The cytotoxicity of 6,7-modified-5,8-quinoxalinedione derivatives and heterocyclic quinoxaline derivatives containing nitrogen (compounds were obtained from the NCI Open Compound Repository, Drug Synthesis and Chemistry Branch, NCI) was evaluated in vitro using an MTT assay on human lung adenocarcinoma cells (PC 14), human gastric adenocarcinoma cells (MKN 45), and human colon 
adenocarcinoma cells (colon 205). Pyrido[1,2-a]imidazo[4,5-g]quinoxaline-6,11-dione 44 was markedly cytotoxic against MKN 45 compared with adriamycin and cis-platin used as reference drugs. The $\mathrm{IC}_{50}$ value of compound 44 was $0.073 \mu \mathrm{M}$ while those of adriamycin and cis-platin were $0.12 \mu \mathrm{M}$ and $2.67 \mu \mathrm{M}$, respectively. In this study, the relationship between structure, redox cycling, and cytotoxicity in the MCF-7 and HL-60 cell lines was investigated (Figure 6) [80].<smiles>O=C1c2nccnc2C(=O)c2c1nc1ccccn21</smiles>

Figure 6. Structure of pyrido[1,2-a]imidazo[4,5-g]quinoxaline-6,11-dione 44.

To evaluate their reactivity for bioreductive activation, the levels of free radicals under aerobic conditions were quantified. Direct ESR evidence of formation was provided. The data suggest that good levels of free radicals are generated in the HL-60 (e.g., the HL-60 myeloid leukemia) and MCF-7 cells (e.g., the MCF-7 breast carcinoma) by compound B. Group B compounds showed good redox cycling in both cell lines (HL-60 and MCF-7 cells). They were cytotoxic in the MCF-7 cell at concentrations down to $10 \mu \mathrm{M}$ (Figure 7).<smiles>Cc1nc2c(nc1C)C(=O)c1ccccc1C2=O</smiles>

Figure 7. Structure of 2,3-dimethylbenzo[g]quinoxaline-5,10-dione 6e.

\section{Conclusions}

Despite the effort made to design benzo[g]quinoxalinedione compounds, there are few efficient synthetic approaches, especially green chemistry approaches. 1,4-diazaanthraquinones stand out because of their wide range of biological activities, including anti-cancer activity. However, exploration of these activities has been limited. These drugs offer a larger repertoire of activities in cancer cells than is currently exploited. The heterocyclic quinones that appeared to be very promising in vitro proved ineffective in studies. One reason for this failure is insufficient understanding of the mechanisms of action of these compounds, in part due to the numerous modes of action of these families of derivatives. The versatility of heterocyclic quinones containing a quinoxaline core and their potential to be selectively toxic to tumor cells hold great promise for anticancer therapy.

Author Contributions: Conceptualization: A.G.G.-T.; methodology: A.G.G.-T.; formal analysis: A.G.G.-T., C.C., T.T.; data curation; A.G.G.-T., C.C., T.T.; writing-original draft preparation: A.G.G.-T.; writing-review and editing: A.G.G.-T.; supervision: P.V. All authors have read and agreed to the published version of the manuscript.

Funding: This research received no external funding.

Acknowledgments: The CNRS and of Aix-Marseille University are acknowledged for financial support.

Conflicts of Interest: The authors declare no conflict of interest.

\section{References}

1. Kohen, E. Cell Structure and Function by Microspectrofluorometry; Academic Press: Cambridge, MA, USA, 2014.

2. Marshall, R.S.; Mayer, S.A. On Call Neurology: On Call Series; Elsevier Health Sciences: London, UK, 2007.

3. Vigny, P.; Amirand-Perchard, C. Cell Structure and Function by Microspectrofluorometry; Elsevier: London, UK, 1989; pp. 229-268. 
4. Volpetti, S.; Zaja, F.; Fanin, R. Pixantrone for the treatment of adult patients with relapsed or refractory aggressive non-Hodgkin B-cell lymphomas. OncoTargets Ther. 2014, 7, 865-872. [CrossRef] [PubMed]

5. Berthet, N.; Boturyn, D.; Constant, J.-F. DNA repair inhibitors. Exp. Opin. Ther. Pat. 1999, 9, 401-415. [CrossRef]

6. Inouye, Y.; Take, Y.; Oogose, K.; Kubo, A.; Nakamura, S. The quinoline quinone as the minimum entity for reverse transcriptase inhibitory activity of streptonigrin. J. Antibiot. Res. 1987, 40, 105-107. [CrossRef] [PubMed]

7. Krapcho, A.P.; Petry, M.E.; Getahun, Z.; Landi, J.J.; Stallman, J., Jr.; Polsenberg, J.F.; Gallagher, C.E.; Maresch, M.J.; Hacker, M.P. 6,9-Bis [(aminoalkyl)amino] benzo[ $g$ ]isoquinoline-5,10-diones. A novel class of chromophore-modified antitumor anthracene-9,10-diones: Synthesis and antitumor evaluations. J. Med. Chem. 1994, 37, 828-837. [CrossRef] [PubMed]

8. Krapcho, A.P.; Landi, J.J.; Hacker, M.P., Jr.; McCormack, J.J. Synthesis and antineoplastic evaluations of 5, 8-bis[(aminoalkyl)amino]-1-azaanthracene-9,10-diones. J. Med. Chem. 1985, 28, 1124-1126. [CrossRef] [PubMed]

9. Hazlehurst, L.A.; Krapcho, A.P.; Hacker, M.P. Comparison of aza-anthracenedione-induced DNA damage and cytotoxicity in experimental tumor cells. Biochem. Pharmacol. 1995, 50, 1087-1094. [CrossRef]

10. Remusat, V.; Terme, T.; Gellis, A.; Rathelot, P.; Vanelle, P. Synthesis of original benzo[ $g$ ]quinoxaline-5,10-diones by bis-S $\mathrm{RN}_{1} 1$ methodology. J. Heterocycl. Chem. 2004, 41, 221-225. [CrossRef]

11. Okada, H.; Shimizu, T. Preparation of Naphthoquinone Derivative for Electrophotographic Photoreceptor; Kyocera Document Solutions: Osaka, Japan, 2017; Volume 31.

12. Hoover, J.R.E.; Day, A.R. Preparation of some 1-alkyl-1,2-dihydro-3-hydroxybenzo[ $g$ ]quinoxaline-5,10-diones. J. Am. Chem. Soc. 1955, 77, 35-37. [CrossRef]

13. Lien, J.-C.; Huang, L.-J.; Teng, C.-M.; Wang, J.-P.; Kuo, S.-C. Synthesis and Aniplatelet, Antiinflammatory and Antiallergic Activities of 2,3-disubstituted 1,4-naphtoquinones. Chem. Pharm. Bull. 1996, 44, 1181-1187. [CrossRef]

14. Anacona, J.R.; Bastardo, E.; Camus, J. Manganese (II) and palladium (II) complexes containing a new macrocyclic Schiff base ligand: Antibacterial properties. Transit. Met. Chem. 1999, 24, 478-480. [CrossRef]

15. Winkelmann, E. 2,3,5,6-Tetra-amino-1,4-benzochinon (TABC): Darstellung, eigenschaften und reaktionen. Tetrahedron 1969, 25, 2427-2454. [CrossRef]

16. Chesneau, B.; Hardouin-Lerouge, M.; Hudhomme, P. A Fused Donor-Acceptor System Based on an Extended Tetrathiafulvalene and a Ruthenium Complex of Dipyridoquinoxaline. Org. Lett. 2010, 12, 4868-4871. [CrossRef] [PubMed]

17. Diaz, R.; Reyes, O.; Francois, A.; Leiva, A.M.; Loeb, B. Synthesis of a new polypyridinic highly conjugated ligand with electron-acceptor properties. Tetrahedron Lett. 2001, 42, 6463-6467. [CrossRef]

18. Giorgi-Renault, S.; Renault, J.; Baron, M.; Servolles, P.; Paoletti, C. Heterocyclic quinones. VI: Synthesis and antitumoral effects of 5,10-benzo[g]quinoxalinediones and aza-analogs. Eur. J. Med. Chem. 1985, 20, 144-148. [CrossRef]

19. Manivannan, R.; Satheshkumar, A.; El-Mossalamy, E.-S.-H.; Al-Harbi, L.M.; Kosa, S.A.; Elango, K.P. Design, synthesis and characterization of indole based anion sensing receptors. New J. Chem. 2015, 39, 3936-3947. [CrossRef]

20. Zhu, L.; Chang, H.; Vavallo, C.L.; Jiang, J.; Zeng, Z.; Yang, J.; Smith, M.D.; Miao, S. Synthesis and properties of tetracyanoquinodimethane derivatives. Heterocycl. Commun. 2018, 24, 249-254. [CrossRef]

21. Anzenbacher, P.; Palacios, M.A., Jr.; Jursikova, K.; Marquez, M. Simple Electrooptical Sensors for Inorganic Anions. Org. Lett. 2005, 7, 5027-5030. [CrossRef]

22. Fauvarque, M.-O.; Mortier, M.; Pillet, C.; Aguilar, C.; Soleilhac, E.; Barette, C.; Remusat, V.; Terme, T.; Vanelle, P. Heterocyclic Naphthoquinones Derivatives for Use in the Treatment of Cancers Including Cushing Disease. U.S. Patent 16/323,691, 6 June 2018.

23. Hosokawa, C.; Morishita, H.; Yoshinaga, T.; Kijima, Y. Material for Organic Electroluminescent Device, Organic Electroluminescent Device, and Organic Electroluminescent Display Device. U.S. Patent 7,326,475, 5 February 2008.

24. Cheesman, G.W.H.; Cookson, R.F. Chemistry of Heterocyclic Compounds; Wiley: Hoboken, NJ, USA, 1979; Volume 35, pp. 730-731.

25. Yamashita, Y.; Suzuki, T.; Miyashi, T. 2,2'-(5,8-Dihydroquinoxaline-5,8-diylidene)bis(1,3-benzodithiole)s. A new type of electron donor. Chem. Lett. 1989, 1607-1610. [CrossRef] 
26. Efimova, G.A.; Efros, L.S. Heterocyclic derivatives based on substituted 1,4-naphthoquinones. II. Synthesis and properties of 2,3-disubstituted benzoquinoxaline-5,10-diones. Zhurnal Organicheskoi Khimii 1966, 2, 1900.

27. Diaz, R.; Francois, A.; Barrera, M.; Loeb, B. Synthesis, characterization and theoretical studies of ruthenium(II) complexes with the quinone functionalized polypyridine ligand, Nqphen. Polyhedron 2012, 39, 59-65. [CrossRef]

28. Foxon, S.P.; Green, C.; Walker, M.G.; Wragg, A.; Adams, H.; Weinstein, J.A.; Parker, S.C.; Meijer, A.J.H.M.; Thomas, J.A. Synthesis, Characterization, and DNA Binding Properties of Ruthenium(II) Complexes Containing the Redox Active Ligand Benzo[i]dipyrido[3,2-a:2', $\left.3^{\prime}-c\right]$ phenazine-11,16-quinone. Inorg. Chem. 2012, 51, 463-471. [CrossRef] [PubMed]

29. Vega-Rodríguez, S.; Jimé>nez-Cataño, R.; Leyva, E.; Loredo-Carrillo, S.E. Intramolecular hydrogen bonds in fluorinated, methoxylated, or unsubstituted 2-(anilino)-1,4-naphthoquinones: A theoretical study. J. Fluorine Chem. 2013, 145, 58-62.

30. Kurban, S.; Deniz, N.G.; Sayil, C. Synthesis and cyclization reactions of novel benzo [a] phenazine-and phenoxazine-5-ones derivatives. Bulg. Chem. Commun. 2016, 48, 43-48.

31. Tuyun, F.; Bayrak, N.; Yıldırı>m, H.; Onul, N.; Kara, E.M.; Celik, B.O. Synthesis and in vitro biological evaluation of aminonaphthoquinones and Benzo[b]phenazine-6,11-dione derivatives as potential antibacterial and antifungal compounds. J. Chem. 2015, 2015, 1-8. [CrossRef]

32. Nakazumi, H.; Kondo, K.; Kitao, T. Synthesis of 7,10-disubstituted benzo[ $b]$ phenazine-6,11-quinones. Synthesis 1982, 10, 878-879. [CrossRef]

33. VanAllan, J.A.; Reynolds, G.A.; Adel, R.E. Polynuclear heterocycles. III. The chlorination and nitration of benzo[b]phenazine. J. Org. Chem. 1963, 28, 520-524. [CrossRef]

34. Kurban, S.; Deniz, N.G.; Sayil, C.; Ozyurek, M.; Guclu, K.; Stasevych, M.; Zvarych, V.; Komarovska-Porokhnyavet, O.; Novikov, V. Synthesis, antimicrobial properties, and inhibition of catalase activity of 1,4-naphtho- and benzoquinone derivatives containing N.-, S.-, O-substituted. Heteroat. Chem. 2019, 2019, 1-12. [CrossRef]

35. Loredo-Carrillo, S.E.; Leyva, E.; Platz, M.S.; Cárdenas-Chaparro, A.; Martínez-Richa, A. Thermolysis of 2-azido-3-(R-anilino)-1,4-naphthoquinones. Nitrene insertion versus hydrogen abstraction. Tetrahedron Lett. 2020, 61, 151731-151735. [CrossRef]

36. Win, T.; Yerushalmi, S.; Bittner, S. Direct nitration of 3-arylamino-2-chloro-1, 4-naphthoquinones. Synthesis 2005, 2005, 1631-1634. [CrossRef]

37. Wasserman, E. Electron spin resonance of nitrenes. Prog. Phys. Org. Chem. 1971, 8, 319-336.

38. Castro, M.A.; Gamito, A.M.; Tangarife-Castano, V.; Roa-Linares, V.; Miguel del Corral, J.M.; Mesa-Arango, A.C.; Betancur-Galvis, L.; Francesh, A.M.; San Feliciano, A. New 1,4-anthracenedione derivatives with fused heterocyclic rings: Synhesis and biological evaluation. RSC Adv. 2015, 5, 1244-1261. [CrossRef]

39. Nakazumi, H.; Agawa, T.; Kitao, T. Synthesis and absorption spectra of 1,4-diazaanthraquinone derivatives. Bull. Chem. Soc. Jpn. 1979, 52, 2445-2446. [CrossRef]

40. Gornostaev, L.; Khalyavina, Y.G.; Lavrikova, T.; Stashina, G.; Firgang, S.; Chernyshev, V. Cyclization of 2-arylamino-1, 4-naphthoquinones to benzo[b]phenazine-6, 11-dione 5-oxides. Russ. Chem. Bull. 2014, 63, 739-743. [CrossRef]

41. Titova, S.; Arinin, A.; Gorelik, M. Ortho-nitrosodiphenylamines in the Fisher-Hepp rearrangement. Zhurnal Organicheskoi Khimii 1986, 22, 1562-1564.

42. Shaikh, I.A.; Johnson, F.; Grollman, A.P. Streptonigrin. 1. Structure-activity relationships among simple bicyclic analogs. Rate dependence of DNA degradation on quinone reduction potential. J. Med. Chem. 1986, 29, 1329-1340. [CrossRef]

43. Han, G.; Shin, K.J.; Kim, D.C.; Yoo, K.H.; Kim, D.J.; Park, S.W. A new synthetic route to 6, 7-dichloro-5, 8-quinoxaline-dione and synthesis of its derivatives. Heterocycles 1996, 43, 2496-2502.

44. Yoo, H.-W.; Suh, M.-E.; Park, S.W. Synthesis and Cytotoxicity of 2-Methyl-4, 9-dihydro-1-substituted-1 $H$-imidazo [4, 5-g] quinoxaline-4, 9-diones and 2, 3-Disubstituted-5, 10-pyrazino [2, 3-g] quinoxalinediones. J. Med. Chem. 1998, 41, 4716-4722. [CrossRef]

45. Bock, H.; Dickmann, P.; Herrmann, H.F. Electron transfer and ion pairing. 18. Radical anions and radical ion pairs of aza-substituted naphtho- and anthraquinones. Zeitschrift für Naturforschung B Chem. Sci. 1991, 46, 326-338. [CrossRef] 
46. Yoo, H.W.; Shin, K.J.; Suh, M.E.; Park, S.W. The Reaction of 6, 7-Dichloro-5, 8-quinoxalinedione with Aromatic and Aliphatic Dinucleophiles and Molecular Modeling Study of Their Intercalation Complexes. Bull. Korean Chem. Soc. 1997, 18, 484-488. [CrossRef]

47. Krapcho, A.P.; Maresch, M.J.; Helgason, A.L.; Rosner, K.E.; Hacker, M.P.; Spinelli, S.; Menta, E.; Oliva, A. The synthesis of 6, 9-bis[(aminoalkyl)amino] substituted benzo[ $g$ ]quinoxaline-, benzo[ $g$ ]quinazoline and benzo[ $g]$ phthalazine-5, 10-diones via regiospecific displacements. J. Heterocycl. Chem. 1993, 30, 1597-1606. [CrossRef]

48. Krapcho, A.P.; Gallagher, C.E.; Hammach, A.; Ellis, M.; Menta, E.; Oliva, A. Synthesis of regioisomeric 6,9-(chlorofluoro)-substituted benzo[ $g$ ]quinoline-5,10-diones, benzo[ $g$ ]isoquinoline-5,10-diones and 6-chloro-9-fluorobenzo[g]quinoxaline-5,10-dione. J. Heterocycl. Chem. 1997, 34, 27-32. [CrossRef]

49. Potts, K.T.; Bhattacharjee, D. Synthesis of 1, 4-Diaminoazaanthraquinone Derivatives. Synthesis 1983, 31-32. [CrossRef]

50. Warren, J.D.; Lee, V.J.; Angier, R.B. Synthesis of 5,8-dihydroxynaphtho[2,3-c][1,2,5]thiadiazole-4,9-dione and 6,9-dihydroxybenzo[g]quinoxaline-5,10-dione. J. Heterocycl. Chem. 1979, 16, 1617-1624. [CrossRef]

51. Potts, K.T.; Bhattacharjee, D.; Walsh, E.B. Cycloaddition routes to azaanthraquinone derivatives. 1. Use of azadienophiles. J. Org. Chem. 1986, 51, 2011-2021. [CrossRef]

52. Newman, M.S.; Ihrman, K.G. The Behavior of o-Aroylbenzoic Acid Types in Acidic Media. J. Am. Chem. Soc. 1958, 80, 3652-3656. [CrossRef]

53. VanAllan, J.A.; Reynolds, G.A.; Adel, R.E. Polynuclear heterocycles. II. Additions reactions of benzophenazines. J. Org. Chem. 1962, 27, 2873-2878. [CrossRef]

54. Kumar, S.; Kumar, N.; Drabu, S. Synthesis of benzo[g]quinoxaline-5,10-dione based pyridine derivatives and their antimycobacterial activity. Orient. J. Chem. 2017, 33, 821-828. [CrossRef]

55. Quiroga, J.; Sanchez, N.E.; Acosta, P.; Insuasty, B.; Abonia, R. Microwave-assisted synthesis of fused pyrazolo[3,4- $b]$ pyrazines by the reaction of ortho-aminonitrosopyrazoles and cyclic $\beta$-diketones. Tetrahedron Lett. 2012, 53, 3181-3187. [CrossRef]

56. Hammershøj, P.; Reenberg, T.K.; Pittelkow, M.; Nielsen, C.B.; Hammerich, O.; Christensen, J.B. Synthesis and Properties of 2, 3-Dialkynyl-1, 4-benzoquinones. Eur. J. Org. Chem. 2006, 2006, 2786-2794. [CrossRef]

57. Kolmer-Anderl, N.; Kolmer, A.; Thiele, C.M.; Rehahn, M. Exploration of the Photodegradation of Naphtho [2, 3-g] quinoxalines and Pyrazino [2, 3-b] phenazines. Chem. Eur. J. 2016, 22, 5277-5287. [CrossRef]

58. Morin, C.; Besset, T.; Moutet, J.-C.; Fayolle, M.; Brückner, M.; Limosin, D.; Becker, K.; Davioud-Charvet, E. The aza-analogues of 1,4-naphthoquinones are potent substrates and inhibitors of plasmodial thioredoxin and glutathione reductases and of human erythrocyte glutathione reductase. Org. Biomol. Chem. 2008, 6, 2731-2742. [CrossRef] [PubMed]

59. Huang, H.; Yan, M.; Chen, J.; Yuan, B.; Chen, G.; Cheng, S.; Huang, D.; Gao, Z.; Cao, C. Identification of ortho-naphthoquinones as anti-AML agents by highly efficient oxidation of phenols. Bioorg. Chem. 2019, 86, 97-102. [CrossRef] [PubMed]

60. Taleb, A.; Alvarez, F.; Nebois, P.; Walchshofer, N. An improved methodology for the preparation of 4, 7-dimethoxy-1H-benzimidazole, a key intermediate in the synthesis of 1-alkyl-1H-benzimidazole-4, 7-diones. Heterocycl. Commun. 2006, 12, 111-114. [CrossRef]

61. Nose, M.; Suzuki, H. A mild one-pot procedure for the polynitration of activated arenes. Convenient preparation of dinitro-and trinitrodialkoxybenzenes. Synthesis 2000, 2000, 1539-1542. [CrossRef]

62. Weinberger, L.; Day, A.R. Syntheses of dimethoxybenzimidazoles, dihydroxybenzimidazoles and imidazo- $p$ benzoquinones. J. Org. Chem. 1959, 24, 1451-1455. [CrossRef]

63. Dwyer, C.L.; Holzapfel, C.W. The nitration of electron-rich aromatics. Tetrahedron 1998, 54, 7843-7848. [CrossRef]

64. Kitahara, Y.; Nakahara, S.; Tanaka, Y.; Kubo, A. Synthesis of 5, 8-quinoxalinediones and 5, 8-quinazolinediones. Heterocycles 1992, 34, 1623-1630.

65. Lee, H.; Cho, S.; Namgoong, K.; Jung, J.-K.; Cho, J.; Yang, S.-I. Synthesis and in vitro evaluation of 7-dialkylaminomethylbenzo[g]quinoxaline-5,10-diones. Bioorg. Med. Chem. Lett. 2004, 14, 1235-1237. [CrossRef]

66. Kwak, J.-H.; Namgoong, K.; Jung, J.-K.; Cho, J.; Kim, H.-M.; Park, S.-G.; Yoo, Y.-A.; Kwon, J.-H.; Lee, H. Synthesis and cytotoxic activities of 2-alkyl-2,3-dihydro-1H-2,6,9-triazacyclopenta[b]anthracene-5,10-diones. Arch. Pharmacal Res. 2008, 31, 995-998. [CrossRef] 
67. Lee, H.; Cho, S.; Choi, B.; Namgoong, K.; Jung, J.-K. Synthesis of 2,3,8-trisubstituted 7H-isoindolo[5,6- $g$ ] quinoxaline-5,7,9,11(8H)-tetraones. Heterocycles 2004, 63, 819-826. [CrossRef]

68. Kita, Y.; Kirihara, M.; Fujii, Y.; Okunaka, R.; Akai, S.; Maeda, H.; Tamura, Y.; Shimooka, K.; Ohishi, H.; Ishida, T. Synthetic anthracyclines: Total synthesis of D-ring pyridine and pyrazine analogs of 11-deoxydaunomycin. Chem. Pharm. Bull. 1991, 39, 857-864. [CrossRef]

69. Tanno, N.; Terashima, S. Asymmetric synthesis of optically active anthracyclinone intermediate and 4-demethoxyanthracyclinones by the use of a novel chiral reducing agent. Chem. Pharm. Bull. 1983, 31, 821-836. [CrossRef]

70. Acton, E.M.; Tong, G.L. Approaches to phenazine-derived N-isosteres of anthracyclinones. J. Heterocycl. Chem. 1981, 18, 1141-1147. [CrossRef]

71. Tišler, M.; Stanovnik, B. Advances in Heterocyclic Chemistry; Elsevier: London, UK, 1968; Volume 9, pp. 211-320.

72. Snyder, C.D.; Rapoport, H. Oxidative cleavage of hydroquinone ethers with argentic oxide. J. Am. Chem. Soc. 1972, 94, 227-231. [CrossRef]

73. Danishefsky, S.; Kitahara, T. Useful diene for the Diels-Alder reaction. J. Am. Chem. Soc. 1974, 96, 7807-7808. [CrossRef]

74. Saenger, W. Principles of Nucleic Acid Structure; Springer: Berlin/Heidelberg, Germany, 2013.

75. Yamashita, Y.; Tsubata, Y.; Suzuki, T.; Miyashi, T.; Mukai, T.; Tanaka, S. Benzo[g][1,2,5]thiadiazolo [3,4-b]quinoxaline-5,10-dione and its selenium analog. An unusual type of quinones. Chem. Lett. 1990, 19, 445-448. [CrossRef]

76. Koyama, J.; Morita, I.; Yamori, T. Correlation between cytotoxic activities and reduction potentials of heterocyclic quinones. Molecules 2010, 15, 6559-6569. [CrossRef]

77. Kim, Y.-S.; Park, S.-Y.; Lee, H.-J.; Suh, M.-E.; Schollmeyer, D.; Lee, C.O. Synthesis and cytotoxicity of 6,11-Dihydro-pyrido- and 6,11-Dihydro-benzo[2,3-b]phenazine-6,11-dione derivatives. Bioorg. Med. Chem. 2003, 11, 1709-1714. [CrossRef]

78. Choudhary, A.; Zachek, B.; Lera, R.F.; Zasadil, L.M.; Lasek, A.; Denu, R.A.; Kim, H.; Kanugh, C.; Laffin, J.J.; Harter, J.M.; et al. Identification of Selective Lead Compounds for Treatment of High-Ploidy Breast Cancer. Mol. Cancer Ther. 2016, 15, 48-59. [CrossRef]

79. Yoo, H.-W.; Lee, Y.-S.; Eun Suh, M.; Kim, D.J.; Park, S.W. Cytotoxic effects of quinoxaline derivatives on human cancer cell lines. Arch. Pharm. 1998, 331, 331-333. [CrossRef]

80. Tudor, G.; Gutierrez, P.; Aguilera-Gutierrez, A.; Sausville, E.A. Cytotoxicity and apoptosis of benzoquinones: Redox cycling, cytochrome $C$ release, and BAD protein expression. Biochem. Pharmacol. 2003, 65, 1061-1075. [CrossRef]

Publisher's Note: MDPI stays neutral with regard to jurisdictional claims in published maps and institutional affiliations.

(C) 2020 by the authors. Licensee MDPI, Basel, Switzerland. This article is an open access article distributed under the terms and conditions of the Creative Commons Attribution (CC BY) license (http://creativecommons.org/licenses/by/4.0/). 